\title{
Recent Advances in Biosorption of Copper and Cobalt by Filamentous Fungi
}

\author{
Leonce Dusengemungu ${ }^{1 *}$, George Kasali ${ }^{1}$, Cousins Gwanama ${ }^{2}$ and \\ Kennedy Ochieng Ouma²
}

${ }^{1}$ School of Mathematics and Natural Sciences, The Copperbelt University, Kitwe, Zambia, ${ }^{2}$ School of Natural Resources,

The Copperbelt University, Kitwe, Zambia

Copper $(\mathrm{Cu})$ and Cobalt $(\mathrm{Co})$ are among the most toxic heavy metals from mining and other industrial activities. Both are known to pose serious environmental concerns, particularly to water resources, if not properly treated. In recent years several filamentous fungal strains have been isolated, identified and assessed for their heavy metal biosorption capacity for potential application in bioremediation of $\mathrm{Cu}$ and $\mathrm{Co}$ wastes. Despite the growing interest in heavy metal removal by filamentous fungi, their exploitation faces numerous challenges such as finding suitable candidates for biosorption. Based on current findings, various strains of filamentous fungi have

OPEN ACCESS

Edited by:

Giovanna Cristina Varese

University of Turin, Italy

Reviewed by:

Grazia Cecchi,

University of Genoa, Italy

Valeria Prigione,

University of Turin, Italy

*Correspondence:

Leonce Dusengemungu

dusengeleonce@yahoo.fr

Specialty section:

This article was submitted to

Microbiotechnology,

a section of the journal

Frontiers in Microbiology

Received: 10 July 2020

Accepted: 30 November 2020

Published: 21 December 2020

Citation:

Dusengemungu L, Kasali G, Gwanama C and Ouma KO (2020)

Recent Advances in Biosorption

of Copper and Cobalt by Filamentous

Fungi. Front. Microbiol. 11:582016.

doi: 10.3389/fmicb.2020.582016 high metal uptake capacity, particularly for $\mathrm{Cu}$ and Co. Several works indicate that Trichoderma, Penicillium, and Aspergillus species have higher $\mathrm{Cu}$ and Co biosorption capacity compared to other fungal species such as Geotrichum, Monilia, and Fusarium. It is believed that far more fungal species with even higher biosorption capability are yet to be isolated. Furthermore, the application of filamentous fungi for bioremediation is considered environmentally friendly, highly effective, reliable, and affordable, due to their low technology pre-requisites. In this review, we highlight the capacity of various identified filamentous fungal isolates for biosorption of copper and cobalt from various environments, as well as their future prospects.

Keywords: copper, cobalt, filamentous fungi, biosorption, bioremediation

\section{INTRODUCTION}

The biosorption of copper and cobalt by filamentous fungi has received a great deal of attention in recent years, as an emerging technology for minimizing the distribution of these heavy metals from mining wastes, e-wastes, and industrial wastewaters (Hussein et al., 2004; Dhankhar and Hooda, 2011; Ahemad and Kibret, 2013). The presence and persistence of elevated levels of heavy metals in the environment causes harmful effects on humans and other organisms mainly due to moderate accumulation over time. Leenu and Sheela (2016) reported that copper and cobalt bioaccumulation in Eichhornia crassipes (Mart) affects the plant growth, especially physiological processes and metabolism. The results of their study indicated that $800 \mu \mathrm{M}$ of $\mathrm{Cu}$ and Co treatment had detrimental effects on the growth rates of E. crassipes especially on the development of leaves, stomata, and petioles. The reduced growth and size of aquatic fauna due to the presence of significantly harmful levels of heavy metals has also been observed by Nakayama et al., 2010). 
Numerous reports have demonstrated that in heavy metal polluted environments, microbial populations develop the ability to adapt to the high contamination levels (Forster, 2003; Narendrula-Kotha and Nkongolo, 2017; Coelho et al., 2020). Nevertheless, there are concerns over heavy metal pollution from industries including mining, electroplating, dyeing, and tannery (Shukla and Vankar, 2014; Kapahi and Sachdeva, 2019). To address the effect of heavy metal contamination, chemical methods such as ion-exchange, electrochemical treatment, and chemical precipitation have been developed to control excess heavy metals in wastewater and agricultural fields (Shukla and Vankar, 2014). These conventional methods are usually expensive and ineffective whenever heavy metal concentrations in the environment occur in very low concentrations. Therefore, the option to complement and integrate conventional methods with biological methods such as filamentous biosorption and bioaccumulation is becoming increasingly attractive (Kapahi and Sachdeva, 2019). The basic and simplified laboratory process for fungal biosorption is demonstrated in Figure 1.

Filamentous fungi are ubiquitous in the environment. The diameter of fungal hyphae is between 2 and $10 \mu \mathrm{m}$ while a fungal mycelium comprises an interconnected network of mmto $\mathrm{cm}$-long hypha. Due to their vegetative features, filamentous fungi are among the most economical biofriendly biosorbents available today (Shah et al., 2020). Also, fungal biomasses can be easily produced by using cheap growth media. Moreover, they are easy to grow at a massive scale, with a considerably high biomass yield. Fungi are highly abundant in industrial waste products after fermentation and possess numerous advantages in comparison to other microorganisms such as bacteria (Table 3; Dhankhar and Hooda, 2011; Cárdenas González et al., 2019). According to Cerino-córdova et al. (2012), Aspergillus terreus Thom (1918), has the capacity to biosorb, $68.52 \%$ of copper from aqueous solutions. Although these results indicate that there is a possibility of using Aspergillus terreus as a biosorbent, its capacity is not yet satisfactory and more research are needed to enhance its chelating ability. Luckily, the investigation of biosorption of $\mathrm{Cu}$ and Co by Aspergillus species and other filamentous fungi can be accomplished at a minimal cost (Drahansky et al., 2016).

The distinctive characteristics of the rigid cell wall of fungi (Table 1) composed of mineral ions and nitrogens, as well as its filamentous branching growth habit, are what make fungi such great decomposers and great candidates for the biosorption of heavy metals (Naveena and Latha, 2018). Filamentous fungi typically accumulate metal ions into their mycelium and spores through the mechanisms that involve the fungal cell wall (intracellular/biosorption and extracellular/adsorption processes) which also plays a significant role for the existence and performance of the fungi, as well as energetic uptake and valence conversion (Siddiquee et al., 2015; Igiri et al., 2018; Naveena and Latha, 2018). The rigid cell wall has numerous advantageous characteristics. For instance, the chitin contains chitosan, a polymer of $\mathrm{N}$-acetyl D-glucosamine, which enhances metal uptake and binding properties (Table 1; Naveena and Latha, 2018).

In addition to their ability to bind metals and withstand high variations in nutrient concentrations and other environmental parameters such as $\mathrm{pH}$, anoxic, and temperature, filamentous fungi are usually used in fermentation industries (Dhankhar and Hooda, 2011; Lakshmi et al., 2018). Thus, it is practical to produce and use fungal biomass at large scale for industrial purposes such as bio-removal of metal ions from highly contaminated effluents. According to Lakshmi et al. (2018), the high number of fungal biosorbents is non-toxic and therefore, they are generally safe and easy to handle.

Microbial diversity is highly influenced by the level of contamination as well as contamination events in different locations. It has been demonstrated that long-term contamination is a crucial factor that determines the quality of water, soil, and microbial community besides environmental circumstances and soil characteristics (Crognale et al., 2017). Some studies have confirmed that prolonged contamination of a particular area positively impacts the abundance and immunity of microbial communities (Brandl et al., 1999; Sutton et al., 2013). In contrast, short-term pollution has a deleterious effect on microbial diversity and density (Bourceret et al., 2016). On the other hand, controversial studies have reported that both short-term and long-term exposure of soil to heavy metals results in a detrimental effect on soil microbial diversity (e.g., Narendrula-Kotha and Nkongolo, 2017). However, the fungal community dominated by Ascomycota isolated from aged multipolluted soils was confirmed to adapt to rich microbial diversity compared to non-polluted areas (Bourceret et al., 2016; Crognale et al., 2017). In this regard, in-depth investigation of fungal tolerance and diversity in heavily contaminated environments especially mining sites is of fundamental importance since fungi represent a large proportion of biodiversity and biological matter. These saprophytes also play an essential role in maintaining proper functioning of the ecological system (Crognale et al., 2017). Taking into account that fungi and other microbial communities are crucial in biogeochemical recycling and influence the availability of metals, it is necessary to acquire in-depth knowledge of the taxonomic and functional diversity of fungal communities in heavy metal contaminated sites (Bourceret et al., 2016; Crognale et al., 2017; Narendrula-Kotha and Nkongolo, 2017).

Several filamentous fungi have been associated with the removal of copper and cobalt from aqueous environments (Table 2). Fungal biomass in large quantities can facilitate cleanup of contaminated waters and restoration of contaminated ecosystems. According to studies by Wang and Chen (2009) and Fu and Wang (2011), fungal biomass has a high affinity for copper and cobalt uptake. Therefore, they are relatively suitable for use in the decontamination of polluted sites. Propositions have been made to use filamentous fungi in combination with other microorganism matrices, such as bacteria, to increase biosorption efficiency. It is suggested that how the combination of fungi and other microorganisms (bacteria, algae, yeast) harvest their full potential for heavy metal biosorption remains a novel research area. The resistance mechanisms developed by these microorganisms mainly for their survival shows that they are highly efficient for detoxifying metal ions in aqueous solutions (Xie et al., 2010; Mohammadian et al., 2017). Developing new technologies for bioremediation is especially relevant in areas 


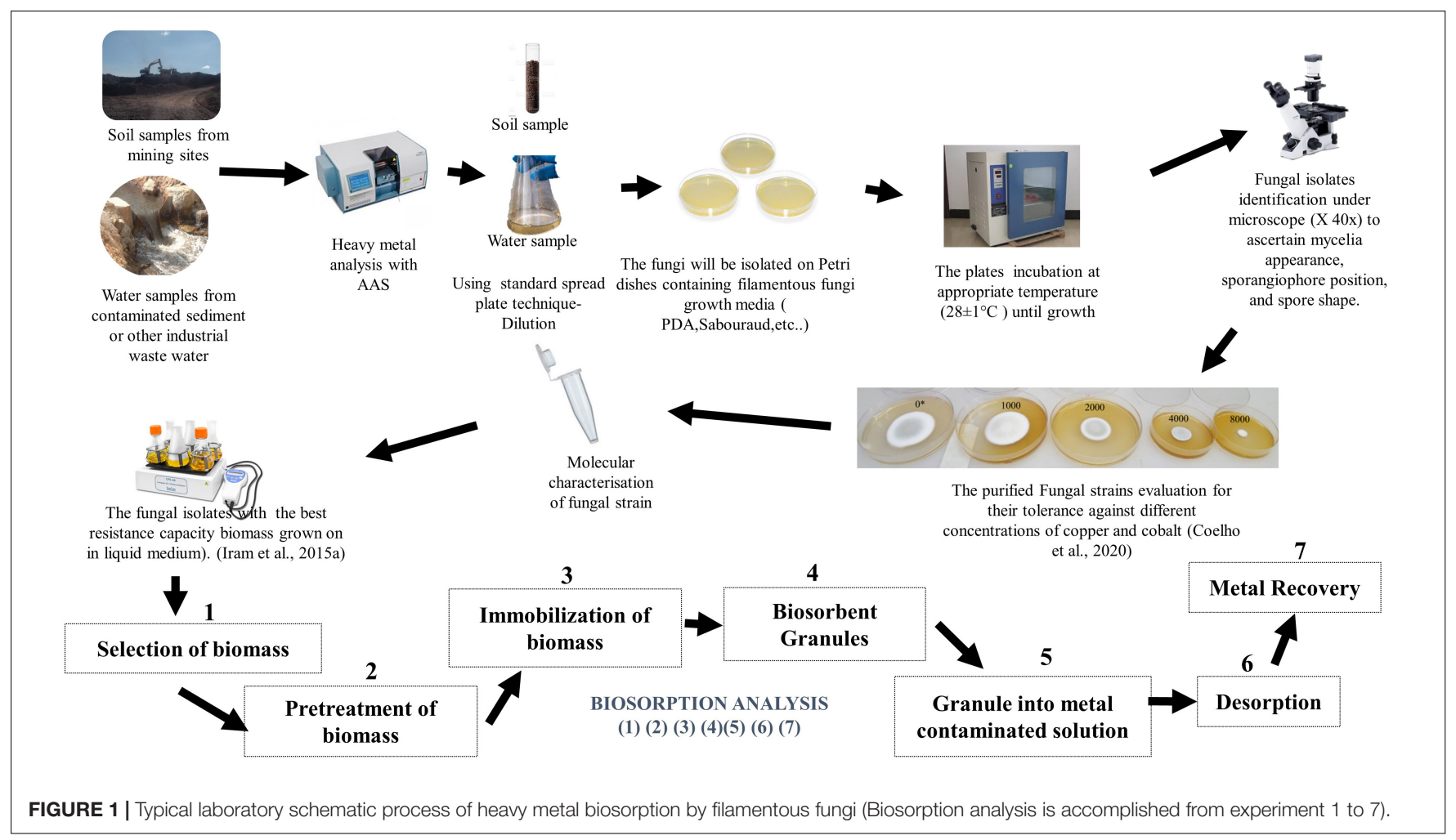

TABLE 1 | Types of Microorganisms used in bioremediation and their cell wall characteristics.

\begin{tabular}{|c|c|c|}
\hline Microorganisms & Cell wall & References \\
\hline & $\begin{array}{l}\text { The common groups in the cell wall are: amine, hydroxide, } \\
\text { carboxyl, sulfate, and phosphate, sulfhydryl }\end{array}$ & Gupta et al., 2000 \\
\hline Fungi & $\begin{array}{l}\text { Has chitin, mineral ions, lipids which contain } \\
\text { polysaccharides and glycoproteins, which also has: amine, } \\
\left.\text { imidazole, phosphate ( } \mathrm{PO}^{3-}{ }^{-}\right) \text {, sulfate, sulfhydryl, and } \\
\text { hydroxyl }\left(\mathrm{COO}^{-}\right) \text {groups (High percentage of cell wall } \\
\text { material compared with other microorganisms) }\end{array}$ & Lakshmi et al., 2018 \\
\hline Algae & $\begin{array}{l}\text { Algal cell walls are mainly cellulosic: the cell walls of brown } \\
\text { algae contain fucoidin and alginic acid. The alginic acid } \\
\text { offers anionic carboxylate and sulfate sites at neutral pH }\end{array}$ & Gupta et al., 2000 \\
\hline Bacteria & $\begin{array}{l}\text { An outer layer of lipopolysaccharide (LPS), phospholipids } \\
\text { and proteins and Functional groups: ketones, aldehydes, } \\
\text { and carboxyl groups }\end{array}$ & Lakshmi et al., 2018 \\
\hline Cyanobacteria & $\begin{array}{l}\text { Peptidoglycans which consist of linear chains of the } \\
\text { disaccharide } \mathrm{N} \text {-acetylglucosamine- } \beta 1,4-\mathrm{N} \text {-acetylmuramic } \\
\text { acid with peptide chains }\end{array}$ & Vannela and Verma, 2006 \\
\hline Yeast & $\begin{array}{l}\text { Contain a microfibrillar structure which is composed of } \\
\text { more than } 90 \% \text { polysaccharides. }\end{array}$ & Lakshmi et al., 2018 \\
\hline
\end{tabular}

with heavy mining activities such as Zambia and The Democratic Republic of the Congo, where copper and cobalt pollutions pose serious public health and environmental hazard. Thus, the restoration of contaminated terrestrial and aquatic environments is necessary in order to reduce the severe impact of copper and cobalt pollution in these areas (Kapungwe, 2013; Ilunga wa Ilunga et al., 2015; Chileshe et al., 2019).

The present review attempts to enumerate the filamentous fungal species/strains/groups with comparatively high capacity to absorb copper and cobalt metal ions from contaminated environments. Progress in the development of technology to reduce the effect caused by copper and cobalt pollution through filamentous fungi biosorption is also discussed. A wide variety of filamentous fungi described in this article can be easily employed to create advanced heavy metal removal systems together with other biotreatment methods for maximum metal uptake efficiency in the future. 
TABLE 2 | The application of different filamentous fungi for the removal of Cu and Co from different environmental matrices.

\begin{tabular}{|c|c|c|c|c|c|}
\hline $\begin{array}{l}\text { Heavy } \\
\text { metal }\end{array}$ & Fungal strain & Environmental matrix & Country & $\begin{array}{l}\text { Removal capacity } \\
\text { (mg/g) }\end{array}$ & References \\
\hline \multirow[t]{26}{*}{$\mathrm{Cu}$} & $\begin{array}{l}\text { Acremonium persicinum } \\
\text { (Nicot) W. Gams, (1971) }\end{array}$ & $\begin{array}{l}\text { Soil samples collected from the } \\
\text { surface layer }(0-30 \mathrm{~cm}) \text { of the } 69 \\
\text { Anguran lead-zinc mining }\end{array}$ & Iran & $50-100$ & $\begin{array}{l}\text { Mohammadian } \\
\text { et al., } 2017\end{array}$ \\
\hline & $\begin{array}{l}\text { Alternaria alternata } \\
\text { Fr. Keissl. (1912) }\end{array}$ & $\begin{array}{l}\text { Samples of water and sediment } \\
\text { from five contaminated sites in the } \\
\text { Moghogha river (Tangier) }\end{array}$ & Morocco & - & $\begin{array}{l}\text { Ezzouhri et al., } \\
2009\end{array}$ \\
\hline & $\begin{array}{l}\text { Alternaria chlamydosporigena } \\
\text { Woudenb. Crous (2013) }\end{array}$ & $\begin{array}{l}\text { Soil samples collected from the } \\
\text { surface layer }(0-30 \mathrm{~cm}) \text { of the } 69 \\
\text { Anguran lead-zinc mining }\end{array}$ & Iran & $50-100$ & $\begin{array}{l}\text { Mohammadian } \\
\text { et al., } 2017\end{array}$ \\
\hline & $\begin{array}{l}\text { Alternaria tenuis } \\
\text { Nees (1816) }\end{array}$ & - & United Kingdom & 22.4 & Somers, 1963 \\
\hline & Aspergillus awamori (Nakaz, 1907) & $\begin{array}{l}\text { The Culture Collection of the } \\
\text { Institute of Microbiology }\end{array}$ & Bulgaria & - & Tsekova, 2000 \\
\hline & $\begin{array}{l}\text { Aspergillus carbonarius } \\
\text { (Bainier) Thom (1916) }\end{array}$ & $\begin{array}{l}\text { Obtained from a fermentation } \\
\text { process }\end{array}$ & Canada & 11.6 & $\begin{array}{l}\text { Al-Asheh and } \\
\text { Duvnjak, } 1995\end{array}$ \\
\hline & $\begin{array}{l}\text { Aspergillus flavus } \\
\text { Link (1809) }\end{array}$ & Soil samples & Pakistan & 93.65 & Iram et al., 2015 \\
\hline & Aspergillus flavus ED4 & Wise park industrial area, Palakkad & India & 10 & $\begin{array}{l}\text { Jayaraman and } \\
\text { Arumugam, } 2014\end{array}$ \\
\hline & $\begin{array}{l}\text { Aspergillus fumigatus } \\
\text { Fresen. (1863) }\end{array}$ & - & China & 40 & Yin et al., 2011 \\
\hline & $\begin{array}{l}\text { Aspergillus niger } \\
\text { Tiegh. (1867) }\end{array}$ & $\begin{array}{l}\text { An open water system at the } \\
\text { Langat River, Selangor }\end{array}$ & Malaysia & $20.910+0.581$ & $\begin{array}{l}\text { Iskandar et al., } \\
2011\end{array}$ \\
\hline & $\begin{array}{l}\text { Aspergillus oryzae } \\
\text { (Ahlb.) Cohn (1884) }\end{array}$ & $\begin{array}{l}\text { Carolina Biological Supply } \\
\text { Company }\end{array}$ & United States & 13.8 & Huang et al., 1991 \\
\hline & $\begin{array}{l}\text { Aspergillus tamarii NRC3 } \\
\text { Kita (1913) }\end{array}$ & Egyptian soil & Egypt & - & Saad et al., 2019 \\
\hline & $\begin{array}{l}\text { Aspergillus terreus } \\
\text { Thom (1918) }\end{array}$ & - & India & $160-180$ & Gulati et al., 2002 \\
\hline & & - & Mexico & 15.24 & $\begin{array}{l}\text { Cerino-córdova } \\
\text { et al., } 2012\end{array}$ \\
\hline & $\begin{array}{l}\text { Aspergillus ustus } \\
\text { (Bainier) Thom and Church (1926) }\end{array}$ & Soil samples & Saudi Arabia & $0.6494 \pm 0.006$ & $\begin{array}{l}\text { Alothman et al., } \\
2019\end{array}$ \\
\hline & $\begin{array}{l}\text { Aspergillus versicolor } \\
\text { (Vuill.) Tirab. (1908) }\end{array}$ & Soil samples & Turkey & $10.08 \pm 0.7$ & Taştan et al., 2010 \\
\hline & $\begin{array}{l}\text { Fomitopsis meliae } \\
\text { (Underw.) Gilb. (1981) }\end{array}$ & $\begin{array}{l}\text { Gemstone and gold mining sites in } \\
\text { Southwestern, Nigeria }\end{array}$ & Nigeria & 0.78 & Oladipo et al., 2018 \\
\hline & $\begin{array}{l}\text { Fusarium flocciferum } \\
\text { Corda (1828) }\end{array}$ & - & Portugal & 2.3 & $\begin{array}{l}\text { Raftos and } \\
\text { Radford, } 2002\end{array}$ \\
\hline & $\begin{array}{l}\text { Fusarium oxysporum } \\
\text { Schltdl. (1824) }\end{array}$ & - & Romania & 2.26 & $\begin{array}{l}\text { Simonescu and } \\
\text { Ferde??, } 2012\end{array}$ \\
\hline & $\begin{array}{l}\text { Fusarium solani } \\
\text { Mart.) Appel and Wollenw. (1910) }\end{array}$ & Topsoil samples near petrol pumps & United Kingdom & $0.66 \pm 0.20$ & Hong et al., 2010 \\
\hline & $\begin{array}{l}\text { Fusarium verticillioides } \\
\text { (Sacc.) Nirenberg } \\
\text { (1976) }\end{array}$ & $\begin{array}{l}\text { Soil samples collected from the } \\
\text { surface layer }(0-30 \mathrm{~cm}) \text { of the } 69 \\
\text { Anguran lead-zinc mining }\end{array}$ & Iran & $100-150$ & $\begin{array}{l}\text { Mohammadian } \\
\text { et al., } 2017\end{array}$ \\
\hline & $\begin{array}{l}\text { Geotrichum sp. } \\
\text { Link (1809) }\end{array}$ & $\begin{array}{l}\text { Agricultural field soil treated with } \\
\text { municipal wastewater/industrial } \\
\text { effluent }\end{array}$ & India & 0.7 & Zafar et al., 2007 \\
\hline & $\begin{array}{l}\text { Hypocrea lixii } \\
\text { Pat. (1891) }\end{array}$ & Topsoil samples near petrol pumps & United Kingdom & $0.54 \pm 0.09$ & Hong et al., 2010 \\
\hline & $\begin{array}{l}\text { Monilia sp. } \\
\text { Bonord. (1851) }\end{array}$ & $\begin{array}{l}\text { Agricultural field soil treated with } \\
\text { municipal wastewater/industrial } \\
\text { effluent }\end{array}$ & India & 0.6 & Zafar et al., 2007 \\
\hline & $\begin{array}{l}\text { Mucor rouxii } \\
\text { (Calmette) Wehmer (1900) }\end{array}$ & $\begin{array}{l}\text { From the company Citric Belge } \\
\text { (Tirlemont, Belgium). }\end{array}$ & South Korea & 200 & Baik et al., 2002 \\
\hline & $\begin{array}{l}\text { Penicillium brevicompactum } \\
\text { Dierckx (1901) }\end{array}$ & $\begin{array}{l}\text { The Collection of the Institute of } \\
\text { Microbiology at the Bulgarian } \\
\text { Academy of Sciences. }\end{array}$ & Bulgaria & 25.32 & $\begin{array}{l}\text { Tsekova et al., } \\
2007\end{array}$ \\
\hline
\end{tabular}


TABLE 2 | Continued

\begin{tabular}{|c|c|c|c|c|c|}
\hline $\begin{array}{l}\text { Heavy } \\
\text { metal }\end{array}$ & Fungal strain & Environmental matrix & Country & $\begin{array}{l}\text { Removal capacity } \\
\text { (mg/g) }\end{array}$ & References \\
\hline & $\begin{array}{l}\text { Penicillium Chrysogenum XJ-1 } \\
\text { Thom (1910) }\end{array}$ & Laboratory strain (GU733711) & China & $42.83 \pm 0.57$ & Xu et al., 2018 \\
\hline & $\begin{array}{l}\text { Penicillium cyclopium } \\
\text { Westling (1911) }\end{array}$ & $\begin{array}{l}\text { The Collection of the Institute of } \\
\text { Microbiology at the Bulgarian } \\
\text { Academy of Sciences }\end{array}$ & Bulgaria & 50.0 & lanis et al., 2006 \\
\hline & $\begin{array}{l}\text { Penicillium griseofulvum } \\
\text { Dierckx (1901) } \\
\text { (Immobilized) }\end{array}$ & $\begin{array}{l}\text { Supplied by Cadila Healthcare Pvt, } \\
\text { Ltd., Gujarat }\end{array}$ & India & 20.47 & Shah et al., 1999 \\
\hline & $\begin{array}{l}\text { Penicillium griseofulvum } \\
\text { Dierckx (1901) } \\
\text { (free) }\end{array}$ & $\begin{array}{l}\text { Supplied by Cadila Healthcare Pvt, } \\
\text { Ltd., Gujarat }\end{array}$ & India & 1.51 & Shah et al., 1999 \\
\hline & $\begin{array}{l}\text { Penicillium italicum } \\
\text { Wehmer (1894) }\end{array}$ & Laboratory strain & United Kingdom & - & $\begin{array}{l}\text { de Rome and } \\
\text { Gadd, } 1987\end{array}$ \\
\hline & $\begin{array}{l}\text { Penicillium notatum } \\
\text { Westling (1911) }\end{array}$ & $\begin{array}{l}\text { 99.999\% pure foils obtained from } \\
\text { Alfa Products, }\end{array}$ & United States & 80 & Siegel et al., 1983 \\
\hline & $\begin{array}{l}\text { Penicillium ochrochloron } \\
\text { Biourge (1923) }\end{array}$ & - & Japan & & Fuwa et al., 1977 \\
\hline & $\begin{array}{l}\text { Penicillium simplicissimum } \\
\text { (Oudem.) Thom (1930) }\end{array}$ & $\begin{array}{l}\text { An open water system at the } \\
\text { Langat River, Selangor }\end{array}$ & Malaysia & $10.767 \pm 0.416$ & $\begin{array}{l}\text { Iskandar et al., } \\
2011\end{array}$ \\
\hline & $\begin{array}{l}\text { Penicillium spinulosum } \\
\text { Thom (1910) }\end{array}$ & - & - & $0.4-2$ & $\begin{array}{l}\text { Townsley and } \\
\text { Ross, } 1985\end{array}$ \\
\hline & $\begin{array}{l}\text { Rhizopus arrhizus } \\
\text { A. Fisch. (1892) }\end{array}$ & $\begin{array}{l}\text { From } \\
\text { The United States Department of } \\
\text { Agriculture Culture Collection }\end{array}$ & Turkey & 7.32 & Aksu, 2003 \\
\hline & $\begin{array}{l}\text { Rhizopus arrhizus } \\
\text { A. Fisch. (1892) }\end{array}$ & $\begin{array}{l}\text { The institute of microbial } \\
\text { technology, Chandigarh }\end{array}$ & India & - & $\begin{array}{l}\text { Preetha and } \\
\text { Viruthagiri, } 2007\end{array}$ \\
\hline & $\begin{array}{l}\text { Rhizopus microsporus } \\
\text { Tiegh. (1875) }\end{array}$ & $\begin{array}{l}\text { Gemstone and gold mining sites in } \\
\text { Southwestern, Nigeria }\end{array}$ & Nigeria & 1.02 & Oladipo et al., 2018 \\
\hline & $\begin{array}{l}\text { Rhizopus oryzae } \\
\text { Went and Prins.Geerl. (1895) }\end{array}$ & $\begin{array}{l}\text { From the company Citric Belge } \\
\text { (Tirlemont, Belgium). }\end{array}$ & South Korea & 101 & Baik et al., 2002 \\
\hline & $\begin{array}{l}\text { Seimatosporium pistaciae } \\
\text { Crous and Mirab. (2014) }\end{array}$ & Soil samples & Iran & $50-100$ & $\begin{array}{l}\text { Mohammadian } \\
\text { et al., } 2017\end{array}$ \\
\hline & $\begin{array}{l}\text { Talaromyces helicus } \\
\text { (Raper and Fennell) C.r. Benj. (1955) }\end{array}$ & $\begin{array}{l}\text { Co-contaminated sludge of the } \\
\text { East Channel, near the YPF-oil } \\
\text { Refinery, La Plata, Argentina. }\end{array}$ & Argentina & - & Romero et al., 2006 \\
\hline & $\begin{array}{l}\text { Trichoderma asperellum } \\
\text { Samuels, Lieckf. and Nirenberg } \\
\text { (1999) }\end{array}$ & An open water system & Malaysia & $15.374 \pm 0.370$ & $\begin{array}{l}\text { Iskandar et al., } \\
2011\end{array}$ \\
\hline & $\begin{array}{l}\text { Trichoderma atroviride } \\
\text { P. Karst. (1892) }\end{array}$ & $\begin{array}{l}\text { Sewage sludge (Water treatment } \\
\text { plant) }\end{array}$ & Spain & - & $\begin{array}{l}\text { López Errasquín } \\
\text { and Vázquez, } 2003\end{array}$ \\
\hline & $\begin{array}{l}\text { Trichoderma ghanense } \\
\text { Yoshim.Doi, Y. Abe and Sugiy. } \\
\text { (1987) }\end{array}$ & Gold and gemstone mine site soils & Nigeria & 1.27 & Oladipo et al., 2018 \\
\hline & $\begin{array}{l}\text { Trichoderma harzianum } \\
\text { Rifai (1969) }\end{array}$ & Contaminated mining soils & - & 650 & $\begin{array}{l}\text { Mohammadian } \\
\text { et al., } 2017\end{array}$ \\
\hline & Trichoderma SP2F1 & Sediment form Phenchala River & Malaysia & 28.75 & $\begin{array}{l}\text { Ting and Choong, } \\
2009\end{array}$ \\
\hline & $\begin{array}{l}\text { Trichoderma virens } \\
\text { (J.H. Mill., Giddens and A.A. Foster) } \\
\text { Arx (1987) } \\
\text { (PDR-28) }\end{array}$ & Rhizosphere soil & South Korea & - & Babu et al., 2014 \\
\hline & $\begin{array}{l}\text { Trichoderma viride } \\
\text { Schumach. (1803) }\end{array}$ & $\begin{array}{l}\text { The soil collected from a metal } \\
\text { polluted site in New Delhi }\end{array}$ & India & 3.4 & Anand et al., 2006 \\
\hline Co & $\begin{array}{l}\text { Aspergillus flavus } \\
\text { Link (1809) }\end{array}$ & $\begin{array}{l}\text { Obtained from the mycology and } \\
\text { plant pathology section, } \\
\text { Department of Botany, Osmania } \\
\text { University, Hyd. N. crassa wild type } \\
\text { (4200 a) }\end{array}$ & India & 50.8 & Rashmi et al., 2004 \\
\hline
\end{tabular}


TABLE 2 | Continued

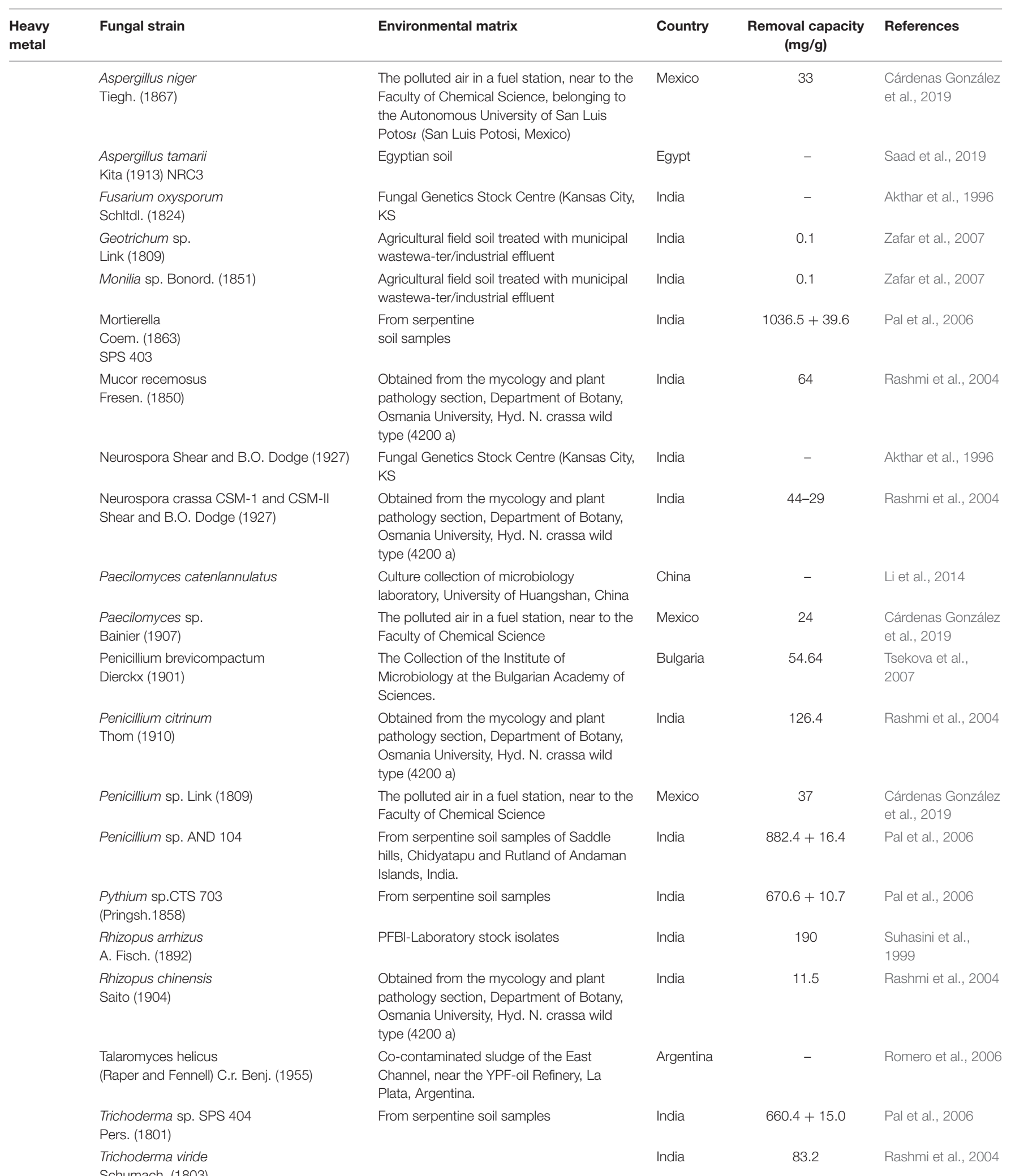


TABLE 3 | The primary advantages and disadvantages of using filamentous fungi in bioaccumulation of heavy metals.

\begin{tabular}{|c|c|c|c|}
\hline Characteristics & Advantages & Disadvantages & References \\
\hline Temperature & $\begin{array}{l}\text { Fungi can grow on various carbon sources such as } \\
\text { fatty acids and oils which also indicate the capacity } \\
\text { to withstand high temperature up to } 40^{\circ} \mathrm{C}\end{array}$ & $\begin{array}{l}\text { High efficiency is only observed at high } \\
\text { temperatures, Inadequate for cold } \\
\text { climates }\end{array}$ & $\begin{array}{l}\text { Ban et al., 2001; Iskandar } \\
\text { et al., } 2011\end{array}$ \\
\hline $\mathrm{pH}$ & $\begin{array}{l}\text { They can grow within a wide range of } \mathrm{pH}(2-9) \\
\text { which is an advantage since most wastewater } \\
\text { varies in } \mathrm{pH} \text { concentration }\end{array}$ & $\begin{array}{l}\text { Some time adjusting } \mathrm{pH} \text { can increase } \\
\text { the efficiency level }\end{array}$ & Ozsoy, 2010 \\
\hline Rate of removal & $\begin{array}{l}\text { Fast and efficient compared to other means of } \\
\text { bioremediation/maximum efficiency for removal of } \\
\text { low concentrations of heavy metals from } \\
\text { wastewater }\end{array}$ & $\begin{array}{l}\text { Depends on the sources of biomass as } \\
\text { well as the concentration of heavy } \\
\text { metals in wastewaters }\end{array}$ & Barakat, 2011 \\
\hline Selectivity & $\begin{array}{l}\text { Depending on the type of heavy metal, can be } \\
\text { modified through bioengineering }\end{array}$ & Low selectivity & $\begin{array}{l}\text { Lakshmi et al., 2018; Igiri } \\
\text { et al., } 2018\end{array}$ \\
\hline Energy requirement & Low & Requires oxygen & $\begin{array}{l}\text { Harms et al., 2011; } \\
\text { Lakshmi et al., } 2018\end{array}$ \\
\hline Effectiveness & $\begin{array}{l}\text { Highly effective (They can supply a high range of } \\
\text { organic substrates }\end{array}$ & & Fu and Wang, 2011 \\
\hline Cost & $\begin{array}{l}\text { Low, can be produced at the minimum operating } \\
\text { cost }\end{array}$ & - & Fan et al., 2008 \\
\hline Reuse and Regeneration & $\begin{array}{l}\text { It protects the environments allowing recovery of } \\
\text { metals and reuses }\end{array}$ & - & Siddiquee et al., 2015 \\
\hline Long-range transport & $\begin{array}{l}\text { Fungi adapt with resource heterogeneity by } \\
\text { translocating resources between different parts of } \\
\text { their mycelium }\end{array}$ & - & Harms et al., 2011 \\
\hline Contamination & $\begin{array}{l}\text {-Low sludge generation compared to other removal } \\
\text { techniques such as precipitation }\end{array}$ & $\begin{array}{l}\text { Might produce toxic substances at low } \\
\text { rates compared with other conventional } \\
\text { methods }\end{array}$ & Fu and Wang, 2011 \\
\hline Variability & $\begin{array}{l}\text { Highly variable (can be used in an extremely } \\
\text { contaminated environment, too acidic, or too dry) } \\
\text { and produce a relatively large amount of biomass }\end{array}$ & - & $\begin{array}{l}\text { Fu and Wang, 2011; Harms } \\
\text { et al., } 2011\end{array}$ \\
\hline
\end{tabular}

\section{POTENTIAL FILAMENTOUS FUNGI SPECIES AND THEIR PROPERTIES IN BIOSORPTION OF COPPER AND COBALT}

Biosorption refers to the natural capacity of biological materials to accumulate heavy metals from diverse locations (mineral ores, mining wastes, industrial wastes and wastewaters, etc.). Biosorption occurs naturally in the environment, and recently, researchers have experimented with the ability of microorganisms to biosorb heavy metals and possibly valuable metals from several locations (Iram et al., 2015). Biosorption is one aspect of biohydrometallurgy based on the interactions between living microorganisms and metallic ions (Iskandar et al., 2011). Two principal bacteria families are used in biohydrometallurgy. These are the chemolithotrophic bacteria such as Thiobacillus thiooxidans Waksman and Joffe (1922) and Thiobacillus caldus Hallberg and Lindström (1995). Other heterotrophic microorganisms that can also be used include fungi, yeast, and other associated species (Johnson, 2014).

For reasons not well understood, the role of fungi species in the biosorption of heavy metals and other biohydrometallurgy purposes has been less regarded for extensive scale application (Borja et al., 2016; Liang and Gadd, 2017). This is despite their undeniable advantages over their counterparts, the acidophilic bacteria, such as their ability to grow over a wide range of
$\mathrm{pH}$ from 1.0 to 9 , and their higher sensitivity and capacity to accumulate more heavy metals $(0.40-700 \mathrm{mg} / \mathrm{g})$ compared to bacteria biosorption $(0.70-500 \mathrm{mg} / \mathrm{g}$ ) (Ahemad and Kibret, 2013). Numerous researches have published findings on the biosorption of heavy metals by filamentous fungi but mostly under controlled laboratory-scale environments (Zafar et al., 2007; Ezzouhri et al., 2009; Siddiquee et al., 2013; Mohammadian et al., 2017). To understand, clearly and in detail, the progress in biosorption of heavy metals by filamentous fungi, our review has focused mainly on the biosorption of copper and cobalt from heavy metal contaminated environments (Table 2).

\section{Aspergillus Species}

The Aspergillus species are filamentous fungi ubiquitous in the environment. They possess many industrial applications, including practical applications in biosorption of heavy metals from contaminated sites. These species have enormous ability to create a metal sink coupled with their capacity to produce organic acids that can bioleach metals. There are four popular species of Aspergillus: A. niger, A. flavus, A. versicolor, and A. tamarii NRC 3 used for biosorption (Oladipo et al., 2018; Table 2).

\section{Aspergillus flavus Link (1809)}

Aspergillus flavus isolated from effluent samples obtained from wise park industrial area, India, was examined for its biosorption ability to uptake $\mathrm{Cu}$ (II). The results demonstrated that $80 \%$ of copper could be biosorbed from an aqueous solution 
(Jayaraman and Arumugam, 2014). The findings confirmed that A. flavus can be classified among potential biosorbents for the clean-up of copper contaminated environments. Their results showed that biosorbents after the removal of copper or other heavy metals could be reused or regenerated again. In addition, the above results agree with the findings by Rao et al. (2002), which indicated that $A$. flavus (DSF-8) could also be used in the bioleaching of copper.

In another study by Qayyum et al. (2019), A. flavus isolated from contaminated soil has shown high effectiveness in the biosorption of heavy metals. The study concluded that with sucrose as a carbon source at $30^{\circ} \mathrm{C}$ and $\mathrm{pH}$ of 7 , bioleaching of $\mathrm{Pb}$, $\mathrm{Cd}$, and $\mathrm{Zn}$ with $\mathrm{A}$. flavus was possible. It was also suggested that the use of A. flavus for contaminated soil bioremediation could be applied for maximum results whenever the optimal conditions for the growth of A. flavus are provided.

Synthetic flocculants can be employed in wastewater treatment, but they mainly have a disadvantage due to their toxicity (David et al., 2019). Therefore, in an attempt to minimize the toxicity and use a more ecofriendly and biodegradable flocculant, A. flavus and Paenibacillus elgii Kim (2004) isolated from wastewater were found more suitable in the production of microbial flocculants which can be used widely for the downstream treatment of wastewater (David et al., 2019).

\section{Aspergillus versicolor (Vuill.) Tirab. (1908)}

Aspergillus versicolor has demonstrated significant affinity to heavy metals under certain $\mathrm{pH}$ ranges. For instance, it has been demonstrated that for $A$. versicolor, maximum $\mathrm{pH}$ values for optimum heavy metal bioaccumulation are around 6 for 50 $\mathrm{mg} / \mathrm{L}$ of $\mathrm{Cr}$ (VI) and $\mathrm{Ni}$ (II) while $\mathrm{pH} 5$ is suitable for $\mathrm{Cu}$ (II) ions with the 99.89, 30.05, and $29.06 \%$ removal efficiencies, respectively (Taştan et al., 2010). Although the biosorption capacity of $A$. versicolor is still unsatisfactory for $\mathrm{Cu}$ removal from aqueous solution, it has a promising future application in biosorption of heavy metals.

\section{Aspergillus niger Tiegh. (1867)}

Previous studies have tested Aspergillus niger for its removal capacity of heavy metals from industrial as well as swine wastewaters. The results indicated that $A$. niger could absorb $45.54 \%$ of $\mathrm{Pb}$ and $59.67 \%$ of $\mathrm{Cd}$ and $91 \%$ of the copper from the swine wastewaters ( $\mathrm{Pal}$ and Basumajumdar, 2002). A study by Kapoor et al. (1999) which also evaluated the ability of live A. niger biomass to uptake $\mathrm{Pb}, \mathrm{Cd}, \mathrm{Cu}$ and $\mathrm{Ni}$ from wastewaters and found that the removal of these heavy metals was higher when the Aspergillus biomass was used compared to granular activated carbon (E-400). The above experiments demonstrate that $A$. niger can be used to accumulate metals from the contaminated environments. However, more research is needed to increase the biosorption capacity of $A$. niger and enhance more efficient use of the fungal.

\section{Aspergillus tamarii NRC 3 Kita (1913)}

Aspergillus tamarii NRC 3 obtained from contaminated Egyptian soil was used as a biosorbent for the bioremoval and bio-recovery of heavy metals (Saad et al., 2019). From the findings, live
A. tamarii NRC 3 biomass could absorb $90.94 \% \mathrm{Cu}$ (II), 29.13 of $\mathrm{Pb}$ (II), $60 \%$ of $\mathrm{Co}$ (II), $40 \%$ of $\mathrm{Ni}$ (II), $34.47 \%$ of $\mathrm{Fe}$ (II), and $11.45 \%$ of $\mathrm{Cr}$ (II) respectively. Their findings concluded that A. tamarii NRC 3 biomass, even though its biosorption process is affected by temperature, $\mathrm{pH}$, metal ions concentration, and changing time through the optimization of these parameters, the performance of A. tamarii can be improved (Saad et al., 2019).

\section{Trichoderma Species}

The Trichoderma spp. are among the highly diverse community of filamentous fungi worldwide. They contain teleomorphs and have been classified into the order of Hypocreales in the Ascomycete division. These species are also among the most culturable fungi whose group members are considered very popular for their biocontrol capacity, which can facilitate to eliminate a broad range of plant pathogenic fungi (Table 2; Nongmaithem et al., 2016). They are also known for plant growth enhancement (Yedidia et al., 1999), inducing oriented and systematic plant defense responses against pathogens (Harman et al., 2004; Nongmaithem et al., 2016). Since the Trichoderma spp. are extremely interactive in soil and plant roots, they play a significant role in the environment by facilitating in the decomposition of plant residues, biodegradation of industrial chemicals as well as bioremoval/bioaccumulation of a wide range of heavy metals from wastewaters and soil, due to their unique cell-wall characteristics which are mainly composed of glucan polymers and chitin (Nongmaithem et al., 2016; Akhtar and Mannan, 2020).

\section{Trichoderma atroviride P. Karst. (1892)}

Trichoderma atroviride has been used for many industrial processes, including the uptake of heavy metals. Trichoderma atroviride obtained from sewage sludge was tested for its ability to tolerate high concentrations of $\mathrm{Cu}, \mathrm{Zn}, \mathrm{Cd}$ (López Errasquín and Vázquez, 2003). It was found that the autolyzed mycelia of T. atroviride reached the highest values of heavy metal removal while the lowest was recorded when glucose was supplemented. This shows that the composition of the medium has an essential effect on metal uptake (López Errasquín and Vázquez, 2003). In a similar study by Yazdani et al. (2009), Trichoderma atroviride extracted from the copper polluted river sediment was found to biosorb between 0.8 and $11.2 \mathrm{mg} / \mathrm{g}$ of $\mathrm{Cu}$ from potato dextrose liquid medium. From the above results, it is confirmed that $T$. atroviride can be used as a bioremediating agent instead of conventional chemical precipitation, chemical oxidation, and reduction methodologies for wastewater treatment.

\section{Trichoderma virens (J.H. Mill., Giddens and A. A. Foster) Arx (1987)}

Trichoderma virens is well known for its ability to produce antibiotics and also its mycoparasitic capacity (Harman et al., 2004). Babu et al. (2014) categorized T. virens as a metal tolerant fungus because of its potential to tolerate heavy metals such as $\mathrm{Pb}, \mathrm{Cd}, \mathrm{Cu}, \mathrm{As}$, and $\mathrm{Zn}$ from the liquid media comprised of $100 \mathrm{mg} / \mathrm{L}$ of heavy metals. Their results also suggested that the T. virens-PDR-28 can be used for plant biomass production 
as well as phytostabilisations in mine tailing soils with high heavy metal levels.

\section{Trichoderma ghanense Yoshim Doi, Y. Abe and Sugiy. (1987)}

Oladipo et al. (2018) assessed Trichoderma ghanense isolated from a gold and gemstone mine site soil for its tolerance to a high, wide range of heavy metals ( $\mathrm{As}, \mathrm{Fe}, \mathrm{Cd}, \mathrm{Cu}, \mathrm{Pb}$ ). Their findings established that $T$. ghanense possesses high resistance to high concentrations of heavy metals, which indicates that it can be used for bioremediation of heavy metal polluted areas. The T. ghanense has also been reported to secrete ligninolytic enzymes that can biodegrade heavy metals and antioxidant enzymes with the capacity to minimize oxidative stress due to heavy metal pollution (Akhtar and Mannan, 2020).

\section{Trichoderma SP2F1}

Ting and Choong (2009) isolated Trichoderma SP2F1 from the sediment samples from Penchala River, Malaysia, highly contaminated with industrial effluents. Their results have demonstrated that Trichoderma SP2F1 was capable of removing $\mathrm{Cu}$ (II) in aqueous solutions. The bioaccumulation capacity of viable SP2F1 to remove copper ions was $19.6 \mathrm{mg} / \mathrm{g}$ while the nonviable SP2F1 cells removal capacity of $28.75 \mathrm{mg} / \mathrm{g}$. This indicates that both viable and non-viable Trichoderma sp. cells can be used to treat sewage wastes or other wastewaters to remove $\mathrm{Cu}$ (II). The potential application of the Trichoderma spp. for biosorption purposes have been thoroughly reviewed by Gupta et al. (2014) and Sharma et al. (2019).

\section{Penicillium Species}

According to Ianis et al. (2006), the young Penicillium spp., mycelia, have a far greater capacity for heavy metal biosorption than the old mycelia. The potential of Penicillium biomass for removing metal ions from wastewaters was also acknowledged by Zafar et al. (2007) and Iskandar et al., 2011). The data presented from their studies showed that Penicillium sp. had higher bioremediation potential for contaminated ecosystems compared to other filamentous fungi strains such as Aspergillus, Trichoderma, Fusarium, Alternaria, Geotrichum, Rhizopus, and Monilia. Zafar et al. (2007) identified several filamentous fungi, including Penicillium spp. from agricultural soil contaminated by heavy metals. Interestingly, it was also noticed that agricultural soil exposed to heavy metal from municipal and industrial wastewaters for more than 20 years possess a wide variety of metal resistant fungi.

\section{Penicillium simplicissimum (Oudem.) Thom (1930)}

Penicillium spp. isolated from contaminated sediment in Malaysia were tested for their potential biosorption capacity (Iskandar et al., 2011). The results indicated promising metal ion inhibitory concentrations of $\mathrm{Co}, \mathrm{Cr}, \mathrm{Cu}, \mathrm{Cd}$, and $\mathrm{Ni}$ from aqueous solutions. The inhibitory concentrations ranged from 4 to $8 \mathrm{mg} / \mathrm{L}$ for Penicillium simplicissimum isolates. These results confer with the study by Mohammadian et al. (2017), which also confirmed that P. simplicissimum has a higher capacity for $\mathrm{Cu}$ (II) uptake compared to other filamentous fungi [Fusarium verticillioides, Acremonium persicinum, Seimatosporium pistaciae Crous and Mirab. (2014), Alternaria chlamydosporigena Woudenb. and Crous (2013)].

\section{Rhizopus arrhizus A. Fisch. (1892)}

The Rhizopus arrhizus is zygomycete fungi whose biomass capacity for uptake of metal ions has been previously reported (Tobin et al., 1987; Pal and Basumajumdar, 2002; Cara et al., 2018).

Copper uptake by $R$. arrhizus biomass ranged between 50 and $150 \mathrm{mg} / \mathrm{mL}$ (de Rome and Gadd, 1987) while the results by Preetha and Viruthagiri (2007) recorded that under optimized process conditions $\left(4.14\right.$ of $\mathrm{pH}, 37.75^{\circ} \mathrm{C}$ of temperature, $53.84 \mathrm{mg} / \mathrm{L}$ of initial copper ion concentration, and $8.17 \mathrm{~g} / \mathrm{L}$ of biomass loading) about $98.34 \%$ copper removal from aqueous solution can be achieved.

Hence, Rhizopus arrhizus is one of the most promising fungi for industrial heavy metal biosorption (Preetha and Viruthagiri, 2007). Research has also established that living microbial biomass of $R$. arrhizus can biosorb $37.785 \mathrm{mg} / \mathrm{g}$ of copper with $100 \mathrm{mg}$ biomass and $19.464 \mathrm{mg} / \mathrm{g}$ of $\mathrm{Cu}$ with $200 \mathrm{mg}$ of biomass (Chauhan et al., 2020).

\section{BIOSORPTION MECHANISMS OF HEAVY METALS BY MICROBIOTA}

The heavy metal accumulation ability of microorganisms such as bacteria (Kumari et al., 2015; Narendrula-Kotha and Nkongolo, 2017), yeast (Bahafid et al., 2017), algae (Mehta and Gaur, 2005; Kipigroch et al., 2016; Bwapwa et al., 2017), and filamentous fungi (Gadd, 1993; More et al., 2010; Liang and Gadd, 2017) has been studied broadly (Figure 2). Their ability for heavy metal removal is relatively higher compared to the conventional non-biological industrial methods. It has been shown that the primary mechanism through which bacteria, filamentous fungi, algae, and yeast accumulate numerous heavy metals is adsorption, which does not require energy for metabolism. Alternatively, in living cells of some of the bacteria, heavy metals are accumulated through absorption, which generally does depend on energy metabolism. Most microbes show the capacity to rapidly absorb a high quantity of heavy metal ions (Ismail and Moustafa, 2016). The primary mechanisms through which microbes immobilize heavy metals are complex and depend on the type of microorganisms (Figure 2).

\section{Biosorption of Heavy Metals by Fungal Species}

In recent years, the bioremoval mechanisms of heavy metals by some fungal species has been partially studied (Figures 2, 3) and the efficiency of such fungal species to remove heavy metals determined. But still, some mechanisms are not well understood (Suhasini et al., 1999; Taştan et al., 2010; Mathew et al., 2016; Acosta-Rodríguez et al., 2018). The sophisticated cell wall structure profoundly influences the biosorption of heavy metals by fungal species (Table 1). For example, the adsorption mechanism in fungi comprises of metals ions on the cell 


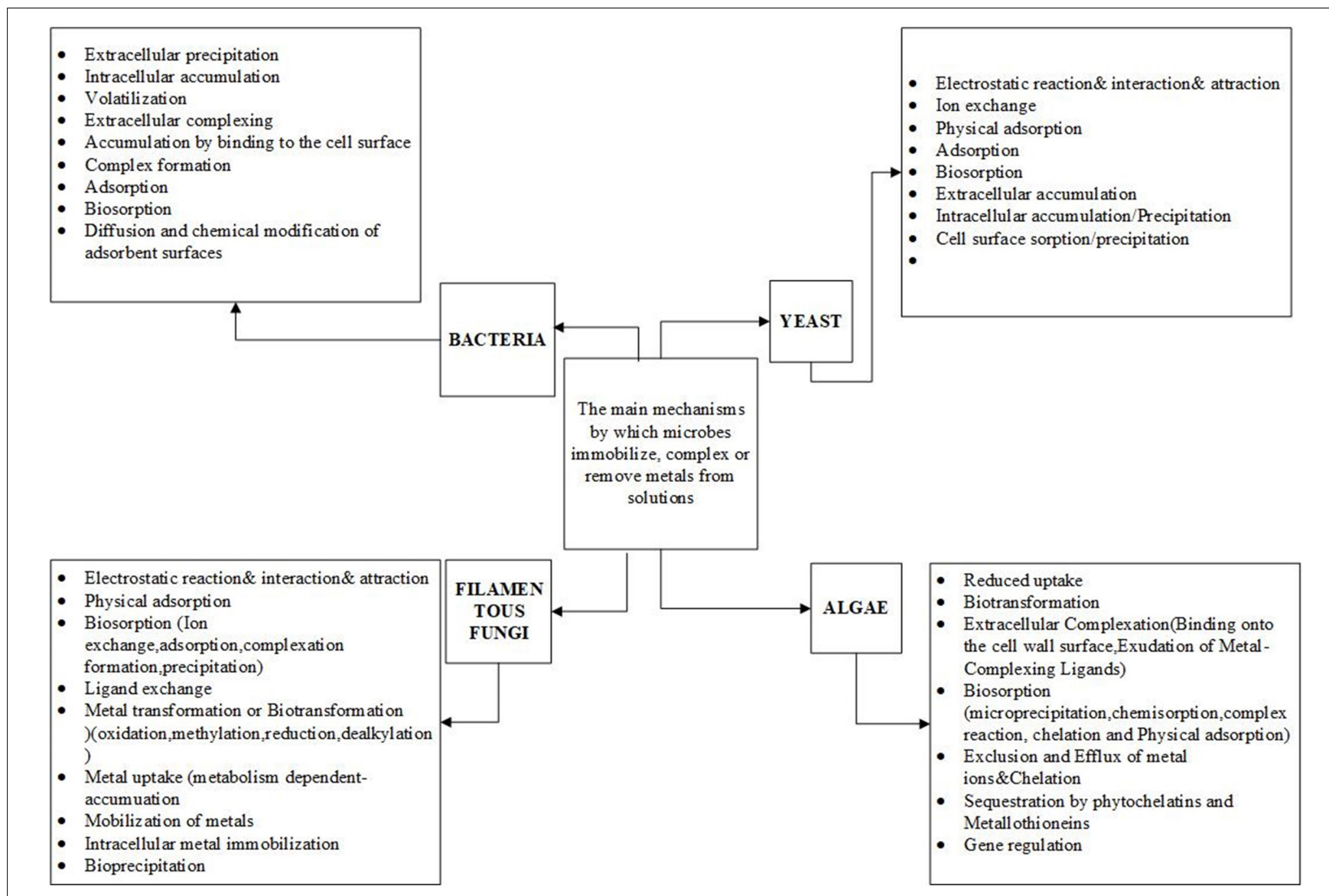

FIGURE 2 | Mechanisms of heavy metals absorption by microorganisms.

surface, from where they can be adsorbed into the cell through one mechanism or combined processes (Dhankhar and Hooda, 2011). There is limited research on the fungal mechanisms for biosorption and the exact performance of fungi has not been clarified (Figure 3). It is also noted that little information is known about the effect of combining fungal biomasses with other microbial biomasses. Therefore, it is assumed that the combinations might improve the removal efficiency in some cases (Dhankhar and Hooda, 2011). However, biosorption competence is also determined by filamentous fungi species and adaptability levels depending on the environmental matrix (air, soil, water) where it was obtained (Oladipo et al., 2018).

The mechanism by which filamentous fungi biosorb metal ions out of aqueous solution is complex due to the fungi cell wall structure (Figure 3; Akthar et al., 1996). The biosorption mechanisms can be classified into two categories based on cell metabolism; the non-metabolism dependent and metabolism-dependent. Depending on the location where the heavy metal ion is extracted from in the solution, biosorption could be arrayed as: (1) Extracellular accumulation (i) adsorption, (ii) ion exchange and complexation, (iii) Redox- reaction; (2) Intracellular accumulation absorption; and (3) Cell surface sorption/Precipitation: metabolic dependent transport.
Further, the past studies on biosorption detected that whenever there was the binding of metal ions on Aspergillus niger, Fusarium oxysporum, Penicillium sp., Neurospora crassa, the release of $\mathrm{Ca}^{2+}$ and $\mathrm{Mg}^{2+}$ was consequently triggered within the medium (Akthar et al., 1996).

\section{FACTORS AFFECTING BIOREMOVAL OF COPPER AND COBALT IONS BY FILAMENTOUS FUNGI}

\section{Effect of the Initial Concentration of Copper and Cobalt}

Earlier studies have shown that the increase of biosorption capacity correlated with both fungal biomasses and the initial cobalt concentration. Cárdenas González et al. (2019) confirmed that the percentage of adsorption decreased whenever Co (II) concentration increased from 300 to $600 \mathrm{mg} / \mathrm{L}$ during the biosorption of cobalt ions by Penicillium spp. and A. niger. In similar biosorption studies, it has been reported that maximum $\mathrm{Cu}$ (II) and Co (II) uptake by Aspergillus tamarii NRC 3 biomass was 92.40 and $60 \%$, respectively, in a solution comprising $5 \mathrm{~g}$ of $A$. tamarii wet biomass (Saad 


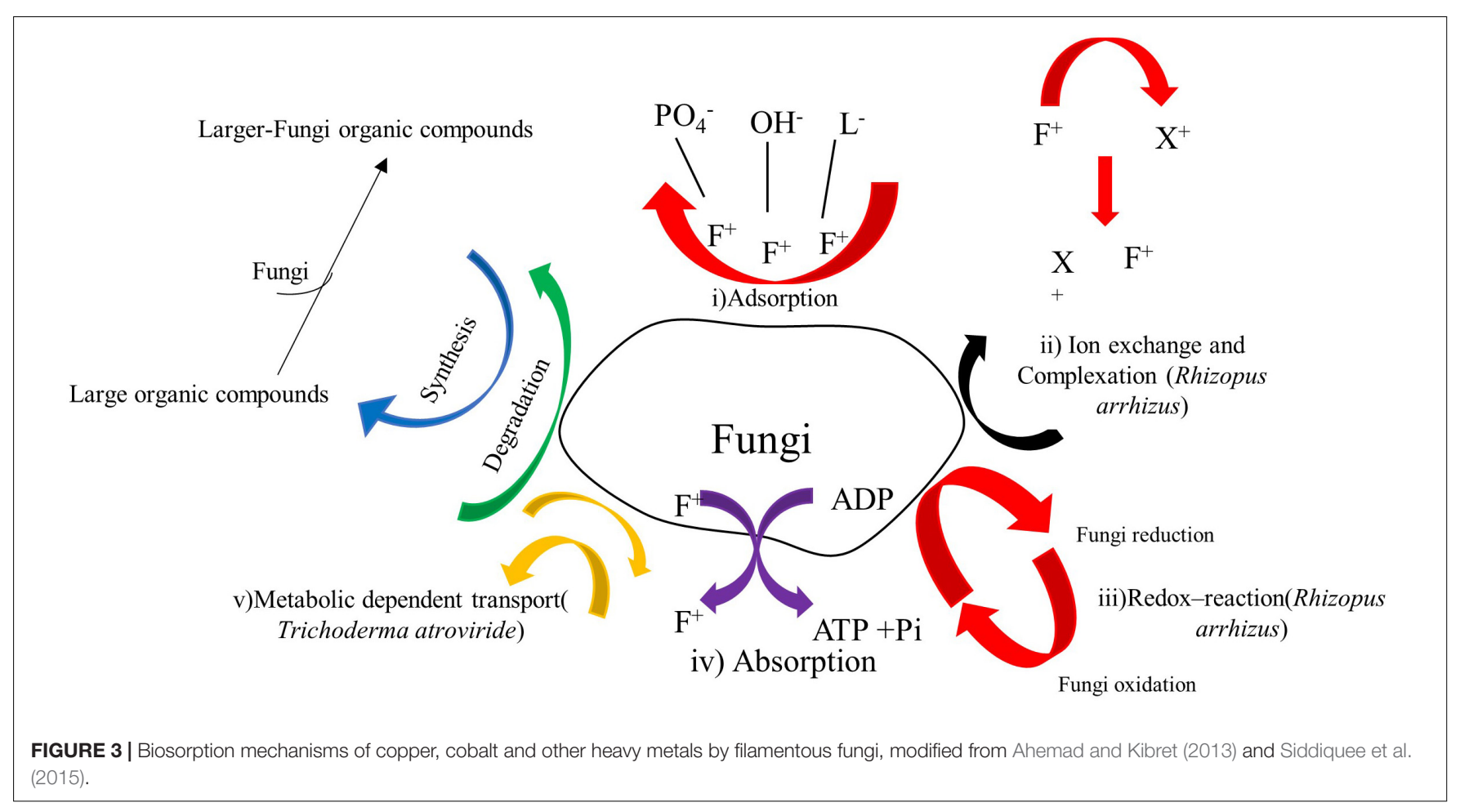

et al., 2019). It has also been observed that the removal capacity differs with fungal species. For example, during cobalt biosorption by filamentous fungi from the soil (Trichoderma, Penicillium, Paecilomyces, Pythium, Rhizopus, Mortierella, and Aspergillus), the initial concentration of Co (II) resulted in increased removal capacity, achieving the maximum value of about $1036.8 \mu \mathrm{M}$ of Co (II) uptake by Mortierella SPS 403 biomass at a maximum of $5.0 \mathrm{mM}$ Co (II) concentration (Pal et al., 2006)

In previous studies on the tolerance of filamentous fungi to heavy metals, Trichoderma atroviride was found to tolerate high copper concentrations from 0 to $300 \mathrm{mg} / \mathrm{L}$ (López Errasquín and Vázquez, 2003). This correlates with the results by Romero et al. (2006), which suggested that the level of the metal accumulated is directly proportional to the heavy metal concentration due to the difference demonstrated by forces applied in the adsorption process. For example, with Talaromyces helicus (Raper and Fennell) C.r. Benj. (1955), it was remarked that the heavy metal uptake also increased from 100 to $200 \mathrm{mg} / \mathrm{L}$ with increasing Co (II) ion concentration from 100 to $600 \mathrm{ppm}$ (Romero et al., 2006). This may be due to the high competition for the functional groups that appear on the surface of the fungal biomass ions (Cárdenas González et al., 2019).

Further studies by Tsekova and Todorova (2002) demonstrated that the microbial growth of Aspergillus niger B-77 related to the initial concentration of $\mathrm{Cu}$ (II). They have also shown that the metal uptake increased with the increase of $\mathrm{Cu}$ (II) concentrations. Where concentrations of 50, 100, and $200 \mathrm{mg} / \mathrm{L} \mathrm{Cu}$ (II) ions were used for $24 \mathrm{~h}$ of cultivation, the accumulation levels were $3.7,7.2$, and $19.2 \mathrm{mg} / \mathrm{g}$, respectively. A higher concentration of initial $\mathrm{Cu}$ (II) negatively affected the uptake of $\mathrm{Cu}$ (II). At $300 \mathrm{mg} / \mathrm{L}$ of $\mathrm{Cu}$ (II), neither microbial growth nor accumulation of $\mathrm{Cu}$ (II) was noticed. The maximum uptake was only observed at $200 \mathrm{mg} / \mathrm{L}$ of $\mathrm{Cu}$ (II) ions (Tsekova and Todorova, 2002).

\section{Effect of Initial Biomass Concentration for Copper and Cobalt Removal}

Jayaraman and Arumugam (2014) demonstrated that the effect of the amount of biomass on the biosorption capacity is increased whenever the amount of fungal biomass is also increased. In the heavy metal solution, when $10 \mathrm{~g}$ rather than $5 \mathrm{~g}$ of the fungal biomass of Paecilomyces spp. was used, nearly $100 \%$ of the heavy metal was absorbed in only $16 \mathrm{~h}$ (Figure 4). Other filamentous fungi like Penicillium spp. and Aspergillus niger depicted high metal biosorption capacity at $24 \mathrm{~h}$ with 100 and $98 \%$ biosorption rates, respectively. In addition, Jayaraman and Arumugam (2014) demonstrated that Aspergillus flavus biomass correlated with the $\mathrm{Cu}$ (II) concentration. It was obvious that by increasing the amount of biomass from 1 to $10 \mathrm{mg} / \mathrm{L}$, the metal removal capacity also extensively augmented with the highest recorded value of $\mathrm{Cu}$ (II) of $26.27 \mathrm{mg} / \mathrm{g}$ metal removal at $4 \mathrm{mg} / \mathrm{mL}$ of biosorbents. The increase in the removal capacity is mainly attributed to the amount of the added biosorbents fixed, the available number of binding sites and the adsorption surface area for metal biosorption (Figure 4) (Cárdenas González et al., 2019). Similar observations have been reported elsewhere with the same effect for P. aeruginosa SPB-1 (Paraneeiswaran et al., 2014), and for Cladonia rangiformis hoffm (Horsfall and Spiff, 2005). The 


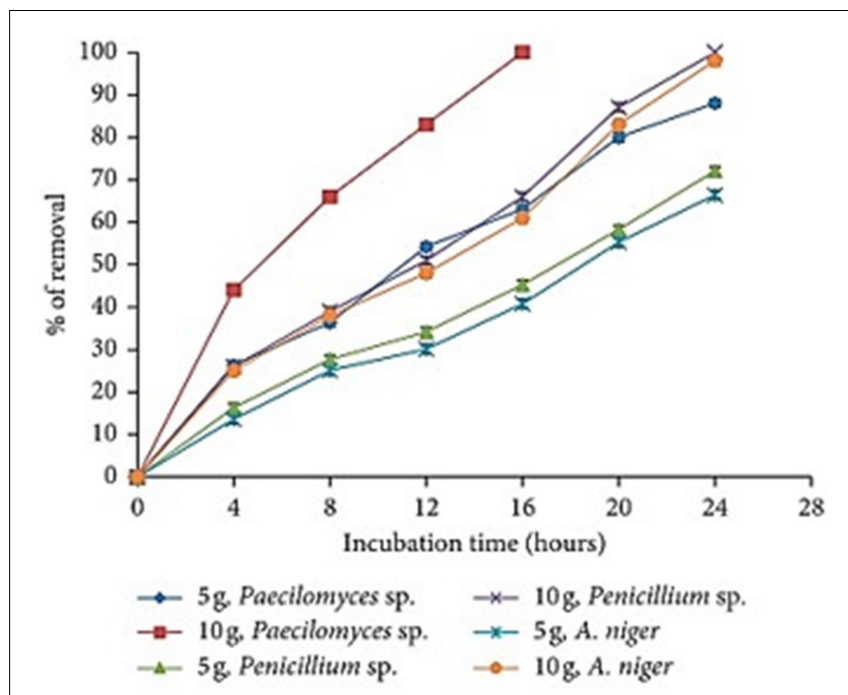

FIGURE 4 | The effect of fungal biomass concentration on the removal of Co (II) (500 mg/L, $100 \mathrm{rpm}, 28^{\circ} \mathrm{C}, \mathrm{pH} 5.0,24$ h) Extracted from Cárdenas González et al. (2019).

same was noted on the biosorption of Co (II) from aqueous solutions by C. nucifera L. (Hymavathi and Prabhakar, 2017).

The desorption percentage from $\mathrm{Cu}$ (II) accumulated biomasses was $80 \%$ under $0.1 \mathrm{~N}$ of $\mathrm{NaOH}$ and $0.1 \mathrm{~N}$ of $\mathrm{HNO}_{3}$, respectively. The regeneration of heavy metals and biosorbents by desorption is very crucial in applying the biosorption process industrially because it determines the cost of the entire process and the potential metal recovery performance (Ekmekyapar et al., 2006).

\section{Effect of pH and Incubation Time on the Removal of Copper and Cobalt}

To understand the effect of both the incubation time and $\mathrm{pH}$ on biosorption of Co (II), $200 \mathrm{mg} / \mathrm{L}$ of the dried fungal biomass was used to determine the maximum biosorption in $24 \mathrm{~h}$ of incubation at pH 5.0 Aspergillus niger, Penicillium spp., and Paecilomyces spp. absorbed 93, 77.5, and 70.4\% of Co (II), respectively (Cárdenas González et al., 2019). The above results concur with those obtained from an experiment with Penicillium cyclopium by Westling (1911) whereby the maximum biosorption of $\mathrm{Cu}$ and $\mathrm{Co}$ was also observed at $\mathrm{pH} 5$ in $24 \mathrm{~h}$ of incubation time. It was also found that with Paecilomyces catenlannulatus, the uptake of Co augmented with the increasing $\mathrm{pH}$ from 4.5 to 7 . The highest biosorption was recorded at $\mathrm{pH}$ 7.0. This was probably due to the $\mathrm{Co}(\mathrm{OH})_{2}(\mathrm{~s})$ precipitation ( $\mathrm{Li}$ et al., 2014). This process can be justified by the fact that there was less competition among positively charged $\mathrm{H}^{+}$and $\mathrm{Co}^{2+}$ functional groups. So as the $\mathrm{pH}$ increases, additional ligands are displayed, and a higher number of negatively charged groups on the adsorbent matrix rise, improving the biosorption of every cationic species (Vafajoo et al., 2018).

Using Aspergillus niger for $\mathrm{Cu}$ (II) removal, multiple biomass samples were incubated at separate time intervals. The highest maximum removal capacity of $A$. niger was observed in $18 \mathrm{~h}$ of $25.2 \mathrm{mg} / \mathrm{g} \mathrm{Cu}$ (II). Similar results have been reported with biosorption of Hg (II) by Rhizopus oligosporus Saito (1905) where the maximum biosorption was $33.33 \mathrm{mg} / \mathrm{g}$ at $\mathrm{pH} 6$ under $6 \mathrm{~h}$ of incubation time (Ozsoy, 2010).

\section{The Effect of the Temperature on the Removal of Co (II) and Cu (II)}

Temperature affects the biosorption of heavy metals. For the removal of Co (II), it has been shown that the highest adsorption capacity occurred at $50 \pm 1^{\circ} \mathrm{C}: 100,97.1$, and 94.1\%, for Paecilomyces sp., Penicillium sp., and A. niger, respectively, over $24 \mathrm{~h}$. These reports are identical to those obtained for $P$. catenlannulatus, as the biosorption of Co (II) augmented with increasing temperature from 20 to $40^{\circ} \mathrm{C}$ (Cárdenas González et al., 2019).

During the removal of $\mathrm{Cu}$ (II), the biosorption capacity of Aspergillus niger was $26.2 \mathrm{mg} / \mathrm{g}$ at $31^{\circ} \mathrm{C}$ in the adsorption medium because the cell wall components stability is mostly influenced by temperature (Saad et al., 2019). It has also been reported that higher temperatures play a significant role in the enhancement of the adsorption ability of the fungal biomasses, which explains that in environments with elevated temperatures, such as in the tropics, it is favorable and practical to use fungal biomasses for bioremediation. High temperatures increase the activation of the adsorbing surfaces and enhance diffusivity of the heavy metal while catalyzing the movements of metal ions (Jayaraman and Arumugam, 2014; Cárdenas González et al., 2019).

\section{SUMMARY AND PROSPECTS}

Industrial wastewaters from mining and other industries released without treatments are harmful to the environment. Therefore, the environmental-friendly methods to dispose or recycle the wastewaters are among the emerging research areas, especially in the optimization of parameters $(\mathrm{pH}$, incubation time, temperature, initial concentration, energy requirements, etc.) for metal ions removal and other contaminants from wastewaters. In developing countries, freshwater resources are scarce. Unfortunately, the available resources in mining areas are contaminated by high discharges of mining wastes into the aquatic systems posing a risk to both these ecosystems and human health (Drahansky et al., 2016; Mwaanga et al., 2019). The high Co (II) and Cu (II) concentrations, especially in mining and industrial wastes are among the substances of health concern since these metals are not biodegradable. Both tend to bioaccumulate in the living organisms and biomagnify along the food web resulting in several diseases and disorders (Drahansky et al., 2016).

The use of fungal biomasses for biosorption has attracted the attention of many researchers due to their numerous advantages (Table 3). According to data in Table 2, fungi have a high capacity to accumulate copper and cobalt. For advancements in bioremediation research, more fungal isolates should be obtained from copper and cobalt mining areas and investigated for their potential application. Their mechanisms of biosorption 
also warrants further research. In addition, the techniques to regenerate and use fungal biomass need further evaluation and improvement for deployment in areas which do not require advanced remediation technologies.

Due to the significant heavy metal pollution in developing countries that rely heavily on mining activities, a possible solution would be to use microorganisms for both biomining and bioremediation due to their eco-friendliness and costeffectiveness. The information in this review shows that filamentous fungi have an exceptional capacity for exploration in the future for industrial-scale biosorption operations. Therefore, more understanding of microorganisms is needed, for instance in developing countries such as Zambia, one of the developing countries with nearly $6 \%$ of the total global reserve of copper and has among the world's largest cobalt reserves that have been mined since the 1900s. There are minimum reports available of microbial and fungal diversity from the contaminated mining and other industrials sites (Staniland et al., 2010). Still, several reports have mentioned the accumulation of toxic heavy metals in the ecosystems (aquatic environments such as rivers, sediments), soil, atmosphere, and plants that can harmfully impact the human health, but also demonstrate the probability of high microbial diversity in such environments (Syakalima et al., 2001; Ikenaka et al., 2010; Elisha et al., 2012; Mugo and Town, 2013; Lindahl, 2014). Fortunately, according to studies conducted elsewhere in heavily contaminated sites, it was noticed that the long-term toxic impact of heavy metal pollutants usually increases the number of indigenous microbial diversities. In particular, bacteria and fungi in such areas were found with high tolerance potential to heavy metals due to the increased adaptation capacity over longtime exposure to contaminants. Some of the fungi are reported to

\section{REFERENCES}

Acosta-Rodríguez, I., Cárdenas-González, J. F., Rodríguez Pérez, A. S., Oviedo, J. T., and Martínez-Juárez, V. M. (2018). Bioremoval of different heavy metals by the resistant fungal strain Aspergillus niger. Bioinorg. Chem. Appl. 2018:3457196. doi: 10.1155/2018/3457196

Ahemad, M., and Kibret, M. (2013). Recent trends in microbial biosorption of heavy metals: a review. Biochem. Mol. Biol. 1, 19-26. doi: 10.12966/bmb.06.02. 2013

Akhtar, N., and Mannan, M. A. (2020). Mycoremediation: expunging environmental pollutants. Biotechnol. Rep. 26:e00452. doi: 10.1016/j.btre. 2020.e00452

Aksu, Z. (2003). The effect of Cd (II), Pb (II) and Cu (II) ions on the growth and bioaccumulation properties of Rhizopus arrhizus. Process Biochem. 39, 105-110. doi: 10.1016/S0032-9592(03)00032-33

Akthar, N., Sivarama Sastry, K., and Maruthi Mohan, P. (1996). Mechanism of metal ion biosorption by fungal biomass. BioMetals 9, 21-28. doi: 10.1007/ BF00188086

Alothman, Z. A., Bahkali, A. H., Khiyami, M. A., Alfadul, S. M., Wabaidur, S. M., Alam, M., et al. (2019). Low cost biosorbents from fungi for heavy metals removal from wastewater. Sep. Sci. Technol. 55, 1766-1775. doi: 10.1080/ 01496395.2019.1608242

Al-Asheh, S., and Duvnjak, Z. (1995). Adsorption of copper and chromium by Aspergillus carbonarius. Biotechnol. Prog. 11, 638-642. doi: 10.1021/ bp00036a006

Anand, P., Isar, J., Saran, S., and Saxena, R. K. (2006). Bioaccumulation of copper by Trichoderma viride. Bioresour. Technol. 97, 1018-1025. doi: 10.1016/j.biortech. 2005.04.046 thrive at high (toxic) metal ions concentrations (Bourceret et al., 2016). Therefore, future research should also focus on identifying and analyzing the potential of these microorganisms in similar sites for potential application in bioremediation.

Based on the data from this review, even though there is considerable knowledge about the fungal community in contaminated areas, there are still numerous gaps in developing countries with high reserves of minerals impacted by the severe effects of high contaminations due to traditional mining and handling of mining wastes. Therefore, further studies are necessary to fill the gaps in our scientific knowledge of these unidentified microbial communities. The wide research and development gap in advanced and environmentally friendly technologies for bioremediation of heavy metal contaminants should also be filled.

\section{AUTHOR CONTRIBUTIONS}

LD researched, wrote, and prepared the tables and figures for the first draft of this review. GK, CG, and KOO contributed to critical inputs, and designed and edited the last draft. All authors listed have made a substantial, direct and intellectual contribution to the work, and approved it for publication.

\section{FUNDING}

This review article writing was supported by the Copperbelt University, African Centre of Excellence for Sustainable Mining (CBU ACESM).

Babu, A. G., Shim, J., Bang, K. S., Shea, P. J., and Oh, B. T. (2014). Trichoderma virens PDR-28: a heavy metal-tolerant and plant growth-promoting fungus for remediation and bioenergy crop production on mine tailing soil. J. Environ. Manage. 132, 129-134. doi: 10.1016/j.jenvman.2013.10.009

Bahafid, W., Joutey, N. T., Asri, M., Sayel, H., Tirry, N., and Ghachtouli, N. (2017). Yeast biomass: an alternative for bioremediation of heavy metals. Yeast - Industrial Applications. ed. A. Morata, (Rijeka: IntechOpen) doi: 10.5772/ intechopen.70559.

Baik, W. Y., Bae, J. H., Cho, K. M., and Hartmeier, W. (2002). Biosorption of heavy metals using whole mold mycelia and parts thereof. Bioresour. Technol. 81, 167-170. doi: 10.1016/s0960-8524(01)00148-1

Ban, K., Kaieda, M., Matsumoto, T., Kondo, A., and Fukuda, H. (2001). Whole cell biocatalyst for biodiesel fuel production utilizing Rhizopus oryzae cells immobilized within biomass support particles. Biochem. Eng. J. 8, 39-43. doi: 10.1016/S1369-703X(00)00133-139

Barakat, M. A. (2011). New trends in removing heavy metals from industrial wastewater. Arab. J. Chem. 4, 361-377. doi: 10.1016/j.arabjc.2010.07.019

Borja, D., Nguyen, K. A., Silva, R. A., Park, J. H., Gupta, V., Han, Y., et al. (2016). Experiences and future challenges of bioleaching research in South Korea. Minerals 6:128. doi: 10.3390/min6040128

Bourceret, A., Cébron, A., Tisserant, E., Poupin, P., Bauda, P., Beguiristain, T., et al. (2016). The bacterial and fungal diversity of an aged PAH- and heavy metalcontaminated soil is affected by plant cover and edaphic parameters. Microb. Ecol. 71, 711-724. doi: 10.1007/s00248-015-0682-688

Brandl, H., Bosshard, R., and Wegmann, M. (1999). Computer-munching microbes: metal leaching from electronic scrap by bacteria and fungi. Process Metall. 9, 569-576. doi: 10.1016/S1572-4409(99)8014 6-80141 
Bwapwa, J. K., Jaiyeola, A. T., and Chetty, R. (2017). Bioremediation of acid mine drainage using algae strains: a review. South African J. Chem. Eng. 24, 62-70. doi: 10.1016/j.sajce.2017.06.005

Cara, M., Sanzani, S. M., Mincuzzi, A., Ippolito, A., Cara, O., and Merkuri, J. (2018). Isolation of Rhizopus arrhizus from Albanian barley. J. Inst. Brew 124 341-343. doi: $10.1002 /$ jib. 521

Cárdenas González, J. F., Rodríguez Pérez, A. S., Vargas Morales, J. M., Martínez Juárez, V. M., Rodríguez, I. A., Cuello, C. M., et al. (2019). Bioremoval of Cobalt(II) from aqueous solution by three different and resistant fungal biomasses. Bioinorg. Chem. Appl. 2019, 1-8. doi: 10.1155/2019/8757149

Cerino-córdova, F. J., García-león, A. M., Soto-regalado, E., and Sánchez-gonzález, M. N. (2012). Experimental design for the optimization of copper biosorption from aqueous solution by Aspergillus terreus. J. Environ. Manage. 95, S77-S82. doi: 10.1016/j.jenvman.2011.01.004

Chauhan, J., Saini, I., and Kaushik, P. (2020). Studies on the biosorption potential of copper by Rhizopus arrhizus Biomass. bioRxiv [preprint] doi: 10.1101/2020. 07.13.201566.

Chileshe, M. N., Syampungani, S., Festin, E. S., Tigabu, M., Daneshvar, A., and Odén, P. C. (2019). Physico-chemical characteristics and heavy metal concentrations of copper mine wastes in Zambia: implications for pollution risk and restoration. J. For. Res. 31, 1283-1293. doi: 10.1007/s11676-019-00921-920

Coelho, E., Reis, T. A., Cotrim, M., Mullan, T. K., and Corrêa, B. (2020). Resistant fungi isolated from contaminated uranium mine in Brazil shows a high capacity to uptake uranium from water. Chemosphere 248:126068. doi: 10.1016/j.chemosphere.2020.126068

Crognale, S., Annibale, A. D., Pesciaroli, L., and Stazi, S. R. (2017). Fungal community structure and as-resistant fungi in a decommissioned gold mine site. Front. Microbiol. 8:2202. doi: 10.3389/fmicb.2017.02202

David, O. M., Oluwole, O. A., Ayodele, O. E., and Lasisi, T. (2019). Characterisation of fungal bioflocculants and its application in water treatment. Curr. J. Appl. Sci. Technol. 34, 1-9. doi: 10.9734/cjast/2019/v34i630159

de Rome, L., and Gadd, G. M. (1987). Copper adsorption by Rhizopus arrhizus, Cladosporium resinae and Penicillium italicum. Appl. Microbiol. Biotechnol. 26, 84-90. doi: 10.1007/BF00282153

Dhankhar, R., and Hooda, A. (2011). Fungal biosorption - an alternative to meet the challenges of heavy metal pollution in aqueous solutions. Environ. Technol. 32, 467-491. doi: 10.1080/09593330.2011.572922

Drahansky, M., Paridah, M. ., Moradbak, A., Mohamed, A. ., Owolabi, F., Abdulwahab T, Asniza, M., et al. (2016). "Application of biosorption for removal of heavy metals from wastewater," in Biosorption, eds J. Derco and B. Vrana (London: Intechopen).

Ekmekyapar, F., Aslan, A., Bayhan, Y. K., and Cakici, A. (2006). Biosorption of copper(II) by nonliving lichen biomass of Cladonia rangiformis hoffm. J. Hazard. Mater. 137, 293-298. doi: 10.1016/j.jhazmat.2006.02.003

Elisha N, Banda, C., and Jhonnah, M. (2012). Air pollution on the copperbelt province of zambia: effects of Sulphur Dioxide on vegetation and humans. J. Nat. Environ. Sci. 3, 34-41.

Ezzouhri, L., Castro, E., Moya, M., Espinola, F., and Lairini, K. (2009). Heavy metal tolerance of filamentous fungi isolated from polluted sites in Tangier, Morocco. African J. Microbiol. Res. 3, 35-48.

Fan, T., Liu, Y., Feng, B., Zeng, G., Yang, C., Zhou, M., et al. (2008). Biosorption of cadmium(II), zinc(II) and lead(II) by Penicillium simplicissimum: isotherms, kinetics and thermodynamics. J. Hazard. Mater. 160, 655-661. doi: 10.1016/j. jhazmat.2008.03.038

Forster, J. W. C. (2003). Biosorbents for Metal Ions. CRC Press. Available online at: https://books.google.co.zm/books?id=xlTBhuYbkC0C\&lpg=PP1\&ots= zCRdgIFEdB\&dq=Biosorbents\%20for\%20Metal\%20Ions.\&lr\&pg=PP1\#v= onepage \&q=Biosorbents\%20for\%20Metal\%20Ions.\&f=false

Fu, F., and Wang, Q. (2011). Removal of heavy metal ions from wastewaters: a review. J. Environ. Manage. 92, 407-418. doi: 10.1016/j.jenvman.2010.11.011

Fuwa, K., Fukami, M., and Toda, S. (1977). Uptake of heavy metals by a coppertolerant fungus, penicillium ochro-chloron. Agric. Biol. Chem. 41, 17-22. doi: 10.1080/00021369.1977.10862460

Gadd, G. M. (1993). Interactions of fungi with toxic metals. New Phytol. 124, 25-60. doi: 10.1111/j.1469-8137.1993.tb03796.x

Gulati, R., Saxena, R. K., and Gupta, R. (2002). Fermentation waste of Aspergillus terreus: a potential copper biosorbent. World J. Microbiol. Biotechnol. 18, 397-401. doi: 10.1023/A:1015540921432
Gupta, R., Ahuja, P., Khan, S., Saxena, R. K., and Mohapatra, H. (2000). Microbial biosorbents: meeting challenges of heavy metal pollution in aqueous solutions. Curr. Sci. 78, 967-973.

Gupta, V. G., Schmoll, M., Herrera-Estrella, A., Upadhyay, R. S., Druzhinina, I., and Tuohy, M. (2014). Biotechnology and biology of Trichoderma. Newnes: Elsevier

Harman, G. E., Howell, C. R., Viterbo, A., Chet, I., and Lorito, M. (2004). Trichoderma species - opportunistic, avirulent plant symbionts. Nat. Rev. Microbiol. 2, 43-56. doi: 10.1038/nrmicro797

Harms, H., Schlosser, D., and Wick, L. Y. (2011). Untapped potential: exploiting fungi in bioremediation of hazardous chemicals. Nat. Rev. Microbiol. 9, 177192. doi: 10.1038/nrmicro2519

Hong, J. W., Park, J. Y., and Gadd, G. M. (2010). Pyrene degradation and copper and zinc uptake by Fusarium solani and Hypocrea lixii isolated from petrol station soil. J. Appl. Microbiol. 108, 2030-2040. doi: 10.1111/j.1365-2672.2009. 04613.x

Horsfall, M., and Spiff, A. I. (2005). Effects of temperature on the sorption of $\mathrm{Pb} 2+$ and $\mathrm{Cd} 2+$ from aqueous solution by caladium bicolor (Wild Cocoyam) biomass. Electron. J. Biotechnol. 8, 162-169. doi: 10.2225/vol8-issue2-fulltext-4

Huang, C., Huang, C. P., and Morehart, A. L. (1991). Proton competition in Cu(II) adsorption by fungal mycelia. Water Res. 25, 1365-1375. doi: 10.1016/00431354(91)90115-90117

Hussein, H., Ibrahim, S. F., Kandeel, K., and Moawad, H. (2004). Biosorption of heavy metals from waste water using Pseudomonas sp. Electron. J. Biotechnol. 7, 45-53. doi: 10.2225/vol7-issue1-fulltext-2

Hymavathi, D., and Prabhakar, G. (2017). Optimization, equilibrium, and kinetic studies of adsorptive removal of cobalt(II) from aqueous solutions using Cocos nucifera L. Chem. Eng. Commun. 204, 1094-1104. doi: 10.1080/00986445.2017. 1338570

Ianis, M., Tsekova, K., and Vasileva, S. (2006). Copper biosorption by penicillium cyclopium: equilibrium and modelling study. Biotechnol. Biotechnol. Equip. 20, 195-201. doi: 10.1080/13102818.2006.10817332

Igiri, B. E., Okoduwa, S. I. R., Idoko, G. O., Akabuogu, E. P., Adeyi, A. O., and Ejiogu, I. K. (2018). Toxicity and bioremediation of heavy metals contaminated ecosystem from tannery wastewater?: a review. J. Toxicol. 2018:2568038

Ikenaka, Y., Nakayama, S. M. M., Muzandu, K., and Choongo, K. (2010). Heavy metal contamination of soil and sediment in Zambia. African J. Environ. Sci. Technol. 4, 729-739 doi: 10.4314/ajest.v4i11.71339

Ilunga wa Ilunga, E., Mahy, G., Piqueray, J., Séleck, M., Shutcha, M. N., Meerts, P., et al. (2015). Plant functional traits as a promising tool for the ecological restoration of degraded tropical metal-rich habitats and revegetation of metalrich bare soils: a case study in copper vegetation of Katanga, DRC. Ecol. Eng. 82, 214-221. doi: 10.1016/j.ecoleng.2015.04.084

Iram, S., Shabbir, R., Zafar, H., and Javaid, M. (2015). Biosorption and Bioaccumulation of copper and lead by heavy metal-resistant fungal isolates. Arab. J. Sci. Eng. 40, 1867-1873 doi: 10.1007/s13369-015-1702-1701

Iskandar, N. L., Zainudin, N. A. I. M., and Tan, S. G. (2011). Tolerance and biosorption of copper $(\mathrm{Cu})$ and lead $(\mathrm{Pb})$ by filamentous fungi isolated from a freshwater ecosystem. J. Environ. Sci. 23, 824-830. doi: 10.1016/S1001-0742(10) 60475-60475

Ismail, I., and Moustafa, T. (2016). Biosorption of heavy metals by bacteria isolated from activated sludge. Heavy Met. Sources, Toxic. Remediat. Tech. 91, 131-174.

Jayaraman, M., and Arumugam, R. (2014). Biosorption of Copper (II) by Aspergillus flavus. Int. J. Sci. Res. 3, 335-340.

Johnson, D. B. (2014). Biomining-biotechnologies for extracting and recovering metals from ores and waste materials. Curr. Opin. Biotechnol. 30, 24-31. doi: 10.1016/j.copbio.2014.04.008

Kapahi, M., and Sachdeva, S. (2019). Bioremediation options for heavy metal pollution. J. Heal. Pollut. 9:191203. doi: 10.5696/2156-9614-9.24. 191203

Kapoor, A., Viraraghavan, T., and Cullimore, D. R. (1999). Removal of heavy metals using the fungus Aspergillus niger. Bioresour. Technol. 70, 95-104. doi: 10.1016/s0960-8524(98)00192-8

Kapungwe, E. M. (2013). Heavy metal contaminated food crops irrigated with wastewater in peri urban areas, Zambia. Open J. Met. 3, 77-88. doi: 10.4236/ ojmetal.2013.32a1010

Kipigroch, K., Janosz-Rajczyk, M., and Skowron-Grabowska, B. (2016). The use of algae in the removal of $\mathrm{cd}$ and $\mathrm{cu}$ in the process of wastewater 
recovery. Desalin. Water Treat. 57, 1508-1514. doi: 10.1080/19443994.2015.104 3491

Kumari, D., Pan, X., Achal, V., Zhang, D., Al-Misned, F. A., and Golam Mortuza, M. (2015). Multiple metal-resistant bacteria and fungi from acidic copper mine tailings of Xinjiang, China. Environ. Earth Sci. 74, 3113-3121. doi: 10.1007/ s12665-015-4349-z

Lakshmi, S., Krishna, R., Lakshmi, S., and Krishna, R. (2018). “Application of biosorption for for removal removal of heavy metals from wastewater," in Biosorption, eds J. Derco and B. Vrana, (London: IntechOpen).

Leenu, S., and Sheela, D. (2016). Research article impact Of Co And Cu (Heavy Metals) on eichhornia crassipes (Mart .) solms, with special reference to bioaccumulation and phytoremediation'. Asian J. Sci. Technol. 7, 2996-2998.

Li, F., Gao, Z., Li, X., and Fang, L. (2014). The effect of environmental factors on the uptake of 60Co by Paecilomyces catenlannulatus. J. Radioanal. Nucl. Chem. 299, 1281-1286. doi: 10.1007/s10967-013-2827-x

Liang, X., and Gadd, G. M. (2017). Metal and metalloid biorecovery using fungi. Microb. Biotechnol. 10, 1199-1205. doi: 10.1111/1751-7915.12767

Lindahl, J. (2014). Environmental Impacts of mining in Zambia, towards better environmental management and sustainable exploitation of mineral resources. Geol. Surv. 127. doi: 10.1111/jicd.12105

López Errasquín, E., and Vázquez, C. (2003). Tolerance and uptake of heavy metals by Trichoderma atroviride isolated from sludge. Chemosphere 50, 137-143. doi: 10.1016/S0045-6535(02)00485-X

Mathew, B. B., Jaishankar, M., Biju, V. G., and Krishnamurthy Nideghatta Beeregowda. (2016). Role of bioadsorbents in reducing toxic metals. J. Toxicol. 2016:4369604. doi: 10.1155/2016/4369604

Mehta, S. K., and Gaur, J. P. (2005). Use of algae for removing heavy metal ions from wastewater: progress and prospects. Crit. Rev. Biotechnol. 25, 113-152. doi: 10.1080/07388550500248571

Mohammadian, E., Ahari, A. B., Arzanlou, M., Oustan, S., and Khazaei, S. H. (2017). Tolerance to heavy metals in filamentous fungi isolated from contaminated mining soils in the Zanjan Province, Iran. Chemosphere 185, 290-296. doi: 10.1016/j.chemosphere.2017.07.022

More, T. T., Yan, S., Tyagi, R. D., and Surampalli, R. Y. (2010). Potential use of filamentous fungi for wastewater sludge treatment. Bioresour. Technol. 101, 7691-7700. doi: 10.1016/j.biortech.2010.05.033

Mugo, T., and Town, C. (2013). Assessment of Water Pollution Arising from Copper Mining in Zambia: A Case Study of Munkulungwe Stream in Ndola, Copperbelt Province. Available online at: https://open.uct.ac.za/handle/11427/ 27984 (accessed June 23, 2020).

Mwaanga, P., Silondwa, M., Kasali, G., and Banda, P. M. (2019). Preliminary review of mine air pollution in Zambia. Heliyon 5:e02485. doi: 10.1016/j.heliyon.2019. e02485

Nakayama, S. M. M., Ikenaka, Y., Muzandu, K., Choongo, K., Oroszlany, B., Teraoka, H., et al. (2010). Heavy metal accumulation in lake sediments, fish (Oreochromis niloticus and Serranochromis thumbergi), and crayfish (Cherax quadricarinatus) in lake itezhi-tezhi and lake Kariba, Zambia. Arch. Environ. Contam. Toxicol. 59, 291-300. doi: 10.1007/s00244-010-9483-9488

Narendrula-Kotha, R., and Nkongolo, K. K. (2017). Bacterial and fungal community structure and diversity in a mining region under long-term metal exposure revealed by metagenomics sequencing. Ecol. Genet. Genom. 2, 13-24. doi: 10.1016/j.egg.2016.11.001

Naveena, J., and Latha, L. (2018). Fungal cell walls as protective barriers for toxic metals. Adv. Med. Biol. 53:19.

Nongmaithem, N., Roy, A., and Bhattacharya, P. M. (2016). Screening of trichoderma isolates for their potential of biosorption of nickel and cadmium. Brazilian J. Microbiol. 47, 305-313. doi: 10.1016/j.bjm.2016.01.008

Oladipo, O. G., Awotoye, O. O., Olayinka, A., Bezuidenhout, C. C., and Maboeta, M. S. (2018). Heavy metal tolerance traits of filamentous fungi isolated from gold and gemstone mining sites. Brazilian J. Microbiol. 49, 29-37. doi: 10.1016/ j.bjm.2017.06.003

Ozsoy, H. D. (2010). Biosorptive removal of $\mathrm{Hg}$ (II) ions by Rhizopus oligosporus produced from corn-processing wastewater. African J. Biotechnol. 9, 8783-8790. doi: 10.5897/AJB10.530

Pal, A., Ghosh, S., and Paul, A. K. (2006). Biosorption of cobalt by fungi from serpentine soil of Andaman. Bioresour. Technol. 97, 1253-1258. doi: 10.1016/ j.biortech.2005.01.043
Pal, T. K., and Basumajumdar, A. (2002). Biosorption of heavy metals by Rhizopus arrhizus and Aspergillus niger. J. Ind. Chem. Soc. 79?: 747-750 ..

Paraneeiswaran, A., Shukla, S. K., Subba Rao, T., and Prashanth, K. (2014). Removal of toxic Co-EDTA complex by a halophilic solar-salt-pan isolate Pseudomonas aeruginosa SPB-1. Chemosphere 95, 503-510. doi: 10.1016/j. chemosphere.2013.09.107

Preetha, B., and Viruthagiri, T. (2007). Application of response surface methodology for the biosorption of copper using Rhizopus arrhizus. J. Hazard. Mater. 143, 506-510. doi: 10.1016/j.jhazmat.2006.09.077

Qayyum, S., Meng, K., Pervez, S., Nawaz, F., and Peng, C. (2019). Optimization of $\mathrm{pH}$, temperature and carbon source for bioleaching of heavy metals by Aspergillus flavus isolated from contaminated soil. Main Gr. Met. Chem. 42, 1-7. doi: 10.1515/mgmc-2018-2038

Raftos, D., and Radford, J. (2002). Bioaccumulation of heavy metals by tunicates. Int. J. Environ. Chem. 14, 40-43.

Rao, D. V., Shivannavar, C. T., and Gaddad, S. M. (2002). Bioleaching of copper from chalcopyrite ore by fungi. Indian J. Exp. Biol. 40, 319-324.

Rashmi, K., Sowjanya, T. N., Mohan, P. M., Balaji, V., and Venkateswaran, G. (2004). Bioremediation of $60 \mathrm{Co}$ from simulated spent decontamination solutions. Sci. Total Environ. 328, 1-14. doi: 10.1016/j.scitotenv.2004.02.009

Romero, M. C., Reinoso, H. E., Urrutia, M. I., and Moreno Kiernan, A. (2006). Biosorption of heavy metals by Talaromyces helicus: a trained fungus for copper and biphenyl detoxification. Electron. J. Biotechnol. 9. doi: 10.2225/vol9-issue3fulltext-11

Saad, A. M., Saad, M. M., Ibrahim, N. A., El-Hadedy, D., Ibrahim, E. I., El-Din, A. Z. K., et al. (2019). Evaluation of Aspergillus tamarii NRC 3 biomass as a biosorbent for removal and recovery of heavy metals from contaminated aqueous solutions. Bull. Natl. Res. Cent. 43:10. doi: 10.1186/s42269-019-004645

Shah, M. P., Vora, S. B., and Dave, S. R. (1999). Evaluation of potential use of immobilized Penicillium griseofulvum in bioremoval of copper. Process Metall. 9, 2004-2007. doi: 10.1016/S1572-4409(99)80112-80116

Shah, S. S., Palmieri, M. C., Sponchiado, S. R. P., and Bevilaqua, D. (2020). Enhanced bio-recovery of aluminum from low-grade bauxite using adapted fungal strains. Brazilian J. Microbiol. 51, 1909-1918. doi: 10.1007/s42770-02000342-w

Sharma, S., Kour, D., Rana, K. L., Dhiman, A., Thakur, S., Thakur, P., et al. (2019). Trichoderma: biodiversity, ecological significances, and industrial applications," in Recent Advancement in White Biotechnology Through Fungi, Diversity and Enzymes Perspectives, eds A. N. Yadav, S. Mishra, S. Singh, A. Gupta, (Cham: Springer International Publishing), 85-120. doi: 10.1007/978-3-030-10480-1_3

Shukla, D., and Vankar, P. S. (2014). Role of trichoderma species in bioremediation process: biosorption studies on hexavalent chromium. Biotechnol. Biol. Trichoderma 2014, 405-412. doi: 10.1016/B978-0-444-59576-8.00030-38

Siddiquee, S., Aishah, S. N., Azad, S. A., Shafawati, S. N., and Naher, L. (2013). Tolerance and biosorption capacity of $\mathrm{Zn} 2+, \mathrm{Pb} 2+, \mathrm{Ni} 3+$ and $\mathrm{Cu} 2+$ by filamentous fungi (Trichoderma harzianum, T. aureoviride and T. virens). $A d v$. Biosci. Biotechnol. 4, 570-583. doi: 10.4236/abb.2013.44075

Siddiquee, S., Rovina, K., and Azad, S. A. (2015). Heavy metal contaminants removal from wastewater using the potential filamentous fungi biomass: a review. J. Microb. Biochem. Technol. 7, 384-393. doi: 10.4172/1948-5948. 1000243

Siegel, S. M., Siegel, B. Z., and Clark, K. E. (1983). Bio-corrosion: solubilization and accumulation of metals by fungi. Water. Air. Soil Pollut. 19, 229-236. doi: 10.1007/BF00599050

Simonescu, C. M., and Ferde??, M. (2012). Fungal biomass for cu(II) uptake from aqueous systems. Polish J. Environ. Stud. 21, 1831-1839.

Somers, E. (1963). The uptake of copper by fungal cells. Ann. Appl. Biol. 51, 425-437. doi: 10.1111/j.1744-7348.1963.tb03710.x

Staniland, S., Coppock, M., Tuffin, M., van Zyl, L., Roychoudhury, A. N., and Cowan, D. (2010). Cobalt uptake and resistance to trace metals in comamonas testosteroni isolated from a heavy-metal contaminated site in the zambian copperbelt. Geomicrobiol. J. 27, 656-668. doi: 10.1080/014904509035 27994

Suhasini, I. P., Sriram, G., Asolekar, S. R., and Sureshkumar, G. K. (1999). Biosorptive removal and recovery of cobalt from aqueous systems. Process Biochem. 34, 239-247. doi: 10.1016/S0032-9592(98)00090-99 
Sutton, N. B., Maphosa, F., Morillo, J. A., Al-Soud, W. A., Langenhoff, A. A. M., Grotenhuis, T., et al. (2013). Impact of long-term diesel contamination on soil microbial community structure. Appl. Environ. Microbiol. 79, 619-630. doi: 10.1128/AEM.02747-2712

Syakalima, M., Choongo, K., Nakazato, Y., Onuma, M., Sugimoto, C., Tsubota, T., et al. (2001). An investigation of heavy metal exposure and risks to wildlife in the kafue flats of zambia. J. Vet. Med. Sci. 63, 315-318. doi: 10.1292/jvms.63.315

Taştan, B. E., Ertugrul, S., and Dönmez, G. (2010). Effective bioremoval of reactive dye and heavy metals by Aspergillus versicolor. Bioresour. Technol. 101, 870-876. doi: 10.1016/j.biortech.2009.08.099

Ting, A. S. Y., and Choong, C. C. (2009). Bioaccumulation and biosorption efficacy of Trichoderma isolate SP2F1 in removing copper $(\mathrm{Cu}(\mathrm{II}))$ from aqueous solutions. World J. Microbiol. Biotechnol. 25, 1431-1437. doi: 10.1007/s11274009-0030-36

Tobin, J. M., Cooper, D. G., and Neufeld, R. J. (1987). Influence of anions on metal adsorption by Rhizopus arrhizus biomass. Biotechnol. Bioeng. 30, 882-886. doi: 10.1002/bit.260300711

Townsley, C. C., and Ross I. S. (1985). Copper uptake by Penicillium spinulosum. Microbios 44, 125-134.

Tsekova, K., Ianis, M., and Ganeva, S. (2007). Biosorption of binary mixtures of copper and cobalt by Penicillium cyclopium biomass. Comptes Rendus L'Academie Bulg. des Sci. 60, 63-70.

Tsekova, K., and Todorova, D. (2002). Copper (II) accumulation and superoxide dismutase activity during growth of Aspergillus niger B-77. Z. Naturforsch. C J. Biosci. 57, 319-322. doi: 10.1515/znc-2002-3-421

Tsekova, K. V. (2000). Copper accumulation by Aspergillus awamori. Folia Microbio 45, 217-220. doi: 10.1007/bf02908947

Vafajoo, L., Cheraghi, R., Dabbagh, R., and McKay, G. (2018). Removal of cobalt (II) ions from aqueous solutions utilizing the pre-treated 2-Hypnea valentiae algae: equilibrium, thermodynamic, and dynamic studies. Chem. Eng. J. 331, 39-47. doi: 10.1016/j.cej.2017.08.019

Vannela, R., and Verma, S. K. (2006). Co2+, Cu2+, and Zn2+ accumulation by cyanobacterium Spirulina platensis. Biotechnol. Prog. 22, 1282-1293. doi: 10. 1021/bp060075s
Wang, J., and Chen, C. (2009). Biosorbents for heavy metals removal and their future. Biotechnol. Adv. 27, 195-226. doi: 10.1016/j.biotechadv.2008.11.002

Xie, X., Fu, J., Wang, H., and Liu, J. (2010). Heavy metal resistance by two bacteria strains isolated from a copper mine tailing in China. African J. Biotechnol. 9, 4056-4066. doi: 10.5897/AJB2010.000-3286

Xu, X., Zhang, Z., Huang, Q., and Chen, W. (2018). Biosorption performance of multimetal resistant fungus Penicillium chrysogenum XJ-1 for removal of $\mathrm{Cu} 2+$ and Cr6+ from aqueous solutions. Geomicrobiol. J. 35, 40-49. doi: 10.1080/ 01490451.2017.1310331

Yazdani, M., Yap, C. K., Abdullah, F., and Tan, S. G. (2009). Trichoderma atroviride as a bioremediator of $\mathrm{Cu}$ pollution: an in vitro study. Toxicol. Environ. Chem. 91, 1305-1314. doi: 10.1080/02772240802616510

Yedidia, I., Benhamou, N., and Chet, I. (1999). Induction of defense responses in cucumber plants (Cucumis sativus L.) by the Biocontrol agent Trichoderma harzianum. Appl. Environ. Microbiol. 65, 1061-1070. doi: 10.1128/aem.65.3. 1061-1070.1999

Yin, Y., Hu, Y., and Xiong, F. (2011). Sorption of Cu(II) and Cd(II) by extracellular polymeric substances (EPS) from Aspergillus fumigatus. Int. Biodeterior. Biodegrad. 65, 1012-1018. doi: 10.1016/j.ibiod.2011.08.001

Zafar, S., Aqil, F., and Ahmad, I. (2007). Metal tolerance and biosorption potential of filamentous fungi isolated from metal contaminated agricultural soil. Bioresour. Technol. 98, 2557-2561. doi: 10.1016/j.biortech.2006.09.051

Conflict of Interest: The authors declare that the research was conducted in the absence of any commercial or financial relationships that could be construed as a potential conflict of interest.

Copyright (c) 2020 Dusengemungu, Kasali, Gwanama and Ouma. This is an openaccess article distributed under the terms of the Creative Commons Attribution License (CC BY). The use, distribution or reproduction in other forums is permitted, provided the original author(s) and the copyright owner(s) are credited and that the original publication in this journal is cited, in accordance with accepted academic practice. No use, distribution or reproduction is permitted which does not comply with these terms. 